\title{
EFFECTS OF MANAGEMENT PRACTICES ON GRASSLAND BIRDS: VESPER SPARROW
}

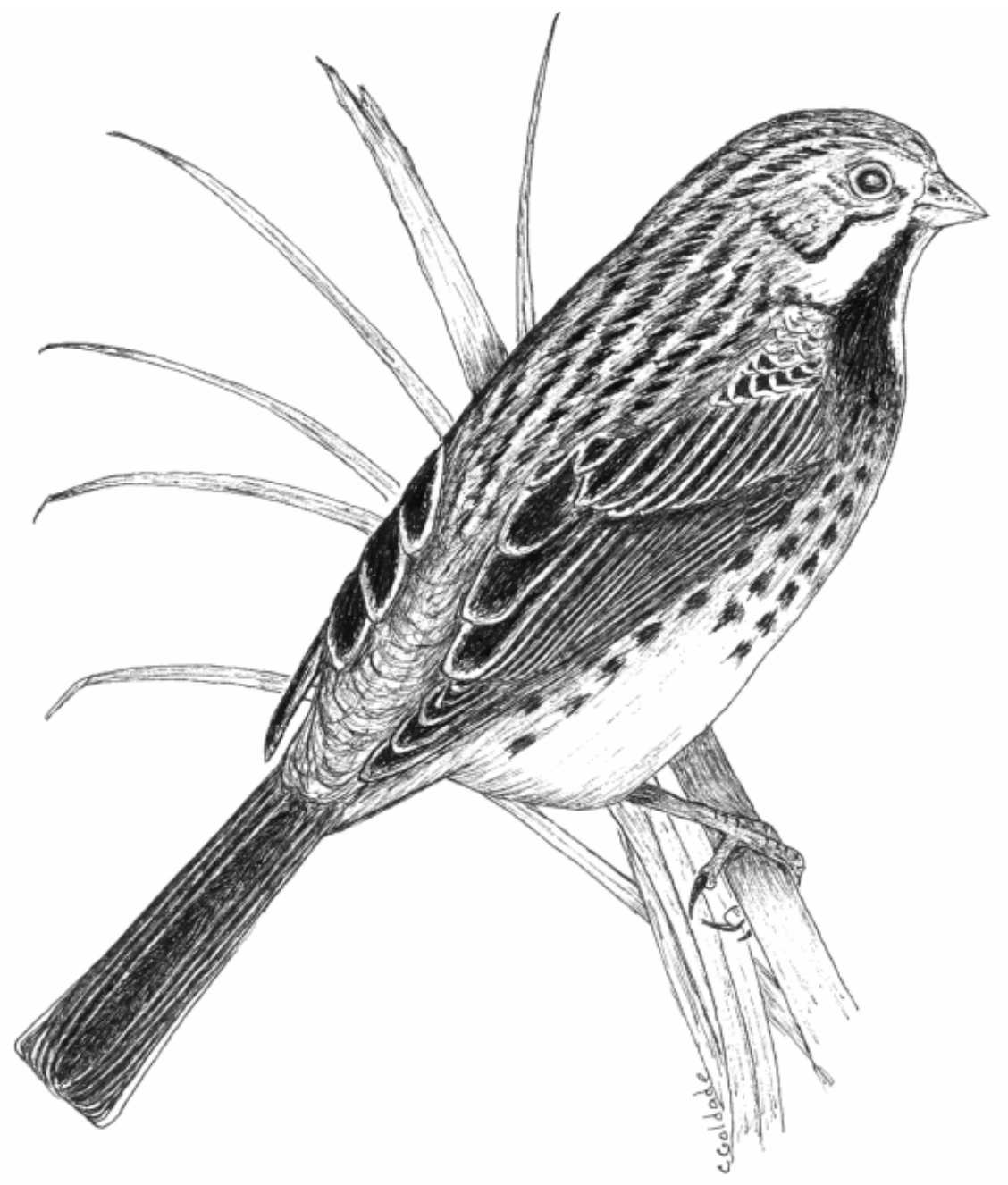

Grasslands Ecosystem Initiative

Northern Prairie Wildlife Research Center U.S. Geological Survey Jamestown, North Dakota 58401 
This report is one in a series of literature syntheses on North American grassland birds. The need for these reports was identified by the Prairie Pothole Joint Venture (PPJV), a part of the North American Waterfowl Management Plan. The PPJV recently adopted a new goal, to stabilize or increase populations of declining grassland- and wetland-associated wildlife species in the Prairie Pothole Region. To further that objective, it is essential to understand the habitat needs of birds other than waterfowl, and how management practices affect their habitats. The focus of these reports is on management of breeding habitat, particularly in the northern Great Plains.

Suggested citation:

Dechant, J. A., M. F. Dinkins, D. H. Johnson, L. D. Igl, C. M. Goldade, and B. R. Euliss. 2000 (revised 2002). Effects of management practices on grassland birds: Vesper Sparrow. Northern Prairie Wildlife Research Center, Jamestown, ND. 41 pages.

Species for which syntheses are available or are in preparation:

American Bittern

Mountain Plover

Marbled Godwit

Long-billed Curlew

Willet

Wilson's Phalarope

Upland Sandpiper

Greater Prairie-Chicken

Lesser Prairie-Chicken

Northern Harrier

Swainson's Hawk

Ferruginous Hawk

Short-eared Owl

Burrowing Owl

Horned Lark

Sedge Wren

Loggerhead Shrike

Sprague's Pipit
Grasshopper Sparrow

Baird's Sparrow

Henslow's Sparrow

Le Conte's Sparrow

Nelson's Sharp-tailed Sparrow

Vesper Sparrow

Savannah Sparrow

Lark Sparrow

Field Sparrow

Clay-colored Sparrow

Chestnut-collared Longspur

McCown's Longspur

Dickcissel

Lark Bunting

Bobolink

Eastern Meadowlark

Western Meadowlark

Brown-headed Cowbird 


\section{EFFECTS OF MANAGEMENT PRACTICES ON GRASSLAND BIRDS:}

\section{VESPER SPARROW}

Jill A. Dechant, Meghan F. Dinkins, Douglas H. Johnson, Lawrence D. Igl, Christopher M. Goldade, and Betty R. Euliss

Series Coordinator: Douglas H. Johnson Series Assistant Coordinator: Lawrence D. Igl

Reviewers: Louis B. Best and D. Glen McMaster

Range Map: Jeff T. Price

Cover Art: Christopher M. Goldade

Major Funding: Prairie Pothole Joint Venture, U.S. Fish and Wildlife Service U.S. Geological Survey

Funding also provided by: U.S. Forest Service

The Nature Conservancy

\section{Collaborators:}

Louis B. Best, Iowa State University

Carl E. Bock, University of Colorado

Brenda C. Dale, Canadian Wildlife Service

Stephen K. Davis, Saskatchewan Wetland Conservation Corporation James J. Dinsmore, Iowa State University

James K. Herkert, Illinois Endangered Species Protection Board

Fritz L. Knopf, Midcontinent Ecological Science Center

Rolf R. Koford, Iowa Cooperative Fish and Wildlife Research Unit

David R. C. Prescott, Alberta NAWMP Centre

Mark R. Ryan, University of Missouri

David W. Sample, Wisconsin Department of Natural Resources

David A. Swanson, Ohio Division of Wildlife

Peter D. Vickery, Massachusetts Audubon Society

John L. Zimmerman (retired), Kansas State University 


\section{ORGANIZATION AND FEATURES OF THIS SPECIES ACCOUNT}

Information on the habitat requirements and effects of habitat management on grassland birds were summarized from information in more than 4,000 published and unpublished papers. A range map is provided to indicate the relative densities of the species in North America, based on Breeding Bird Survey (BBS) data. Although birds frequently are observed outside the breeding range indicated, the maps are intended to show areas where managers might concentrate their attention. It may be ineffectual to manage habitat at a site for a species that rarely occurs in an area. The species account begins with a brief capsule statement, which provides the fundamental components or keys to management for the species. A section on breeding range outlines the current breeding distribution of the species in North America, including areas that could not be mapped using BBS data. The suitable habitat section describes the breeding habitat and occasionally microhabitat characteristics of the species, especially those habitats that occur in the Great Plains. Details on habitat and microhabitat requirements often provide clues to how a species will respond to a particular management practice. A table near the end of the account complements the section on suitable habitat, and lists the specific habitat characteristics for the species by individual studies. A special section on prey habitat is included for those predatory species that have more specific prey requirements. The area requirements section provides details on territory and home range sizes, minimum area requirements, and the effects of patch size, edges, and other landscape and habitat features on abundance and productivity. It may be futile to manage a small block of suitable habitat for a species that has minimum area requirements that are larger than the area being managed. The Brown-headed Cowbird (Molothrus ater) is an obligate brood parasite of many grassland birds. The section on cowbird brood parasitism summarizes rates of cowbird parasitism, host responses to parasitism, and factors that influence parasitism, such as nest concealment and host density. The impact of management depends, in part, upon a species' nesting phenology and biology. The section on breeding-season phenology and site fidelity includes details on spring arrival and fall departure for migratory populations in the Great Plains, peak breeding periods, the tendency to renest after nest failure or success, and the propensity to return to a previous breeding site. The duration and timing of breeding varies among regions and years. Species' response to management summarizes the current knowledge and major findings in the literature on the effects of different management practices on the species. The section on management recommendations complements the previous section and summarizes specific recommendations for habitat management provided in the literature. If management recommendations differ in different portions of the species' breeding range, recommendations are given separately by region. The literature cited contains references to published and unpublished literature on the management effects and habitat requirements of the species. This section is not meant to be a complete bibliography; a searchable, annotated bibliography of published and unpublished papers dealing with habitat needs of grassland birds and their responses to habitat management is posted at the Web site mentioned below.

This report has been downloaded from the Northern Prairie Wildlife Research Center WorldWide Web site, www.npwrc.usgs.gov/resource/literatr/grasbird/grasbird.htm. Please direct comments and suggestions to Douglas H. Johnson, Northern Prairie Wildlife Research Center, U.S. Geological Survey, 8711 37th Street SE, Jamestown, North Dakota 58401; telephone: 701253-5539; fax: 701-253-5553; e-mail: Douglas_H_Johnson@usgs.gov. 


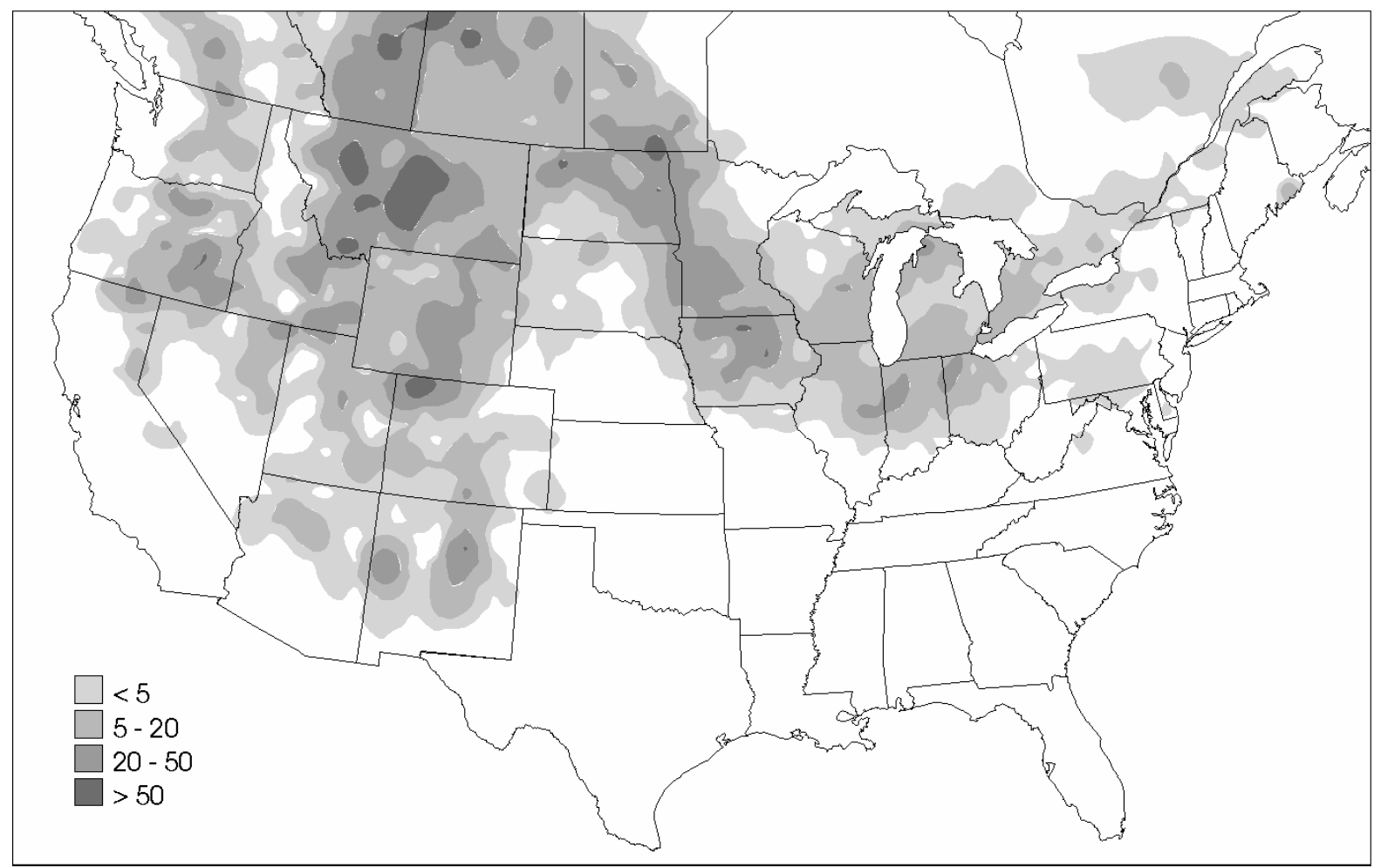

Figure. Breeding distribution of Vesper Sparrow in the United States and southern Canada, based on Breeding Bird Survey data, 1985-1991. Scale represents average number of individuals detected per route per year. Map from Price, J., S. Droege, and A. Price. 1995. The summer atlas of North American birds. Academic Press, London, England. 364 pages.

Keys to management include providing areas of dry, sparse vegetation or edge habitat between forests and fields, and providing elevated song perches.

\section{Breeding range:}

Vesper Sparrows breed from the southern Northwest Territories to southern British Columbia, throughout Alberta, all but the northeastern tip of Saskatchewan, to southern Manitoba, southern Ontario, southern Quebec, New Brunswick, Prince Edward Island, and Nova Scotia, south to central California, New Mexico, northeastern Nebraska, and northern Missouri, and east to Illinois, northern Virginia, Rhode Island, and Maine (National Geographic Society 1999). (See figure for the relative densities of Vesper Sparrows in the United States and southern Canada, based on Breeding Bird Survey data.)

\section{Suitable habitat:}

Vesper Sparrows prefer dry, open areas with short, sparse and patchy vegetation (Roberts 1932, Wiens 1969, Harrison 1974, Skinner et al. 1984, Sample 1989). However, they may be found in a variety of habitats, including shortgrass, mixed-grass, and tallgrass prairie; semidesert grasslands; sagebrush (Artemisia); pastures; hayland; planted cover (such as Conservation Reserve Program [CRP] fields, Permanent Cover Program [PCP] fields, and dense nesting cover 
[DNC]); cropland; shrubby grasslands; oldfields; orchards; woodland edge; shelterbelts; highway rights-of-way; and jack pine (Pinus banksiana) barrens (Saunders 1914; Rand 1948; Batts 1958; Graber and Graber 1963; Berger 1968; Best 1972; Maher 1974; Fautin 1975; Salt and Salt 1976; Emmerich 1978; Johnsgard 1980; Faanes 1981; Yahner 1982; Sample 1989; Dhol et al. 1994; Hartley 1994a,b; Faanes and Lingle 1995; Best et al. 1997; Prescott 1997; McMaster and Davis 1998). In Colorado, Bock et al. (1999) compared the abundance of Vesper Sparrows between upland (mixed-grass prairie) and lowland (tallgrass or tame hayland) grasslands. Vesper Sparrows were significantly more abundant on upland than on lowland plots. Within grazed short- and mixed-grass prairie and shrubsteppe in Colorado, Montana, Nebraska, North Dakota, South Dakota, and Wyoming, Vesper Sparrows were most abundant in shrubsteppe (Kantrud 1982). Vesper Sparrows use transition zones between ecosystems, such as the zone between shortgrass prairie and conifer woodland in Wyoming (Finzel 1964), and the zone (parkland fringe) between mixed-grass prairie and parkland in Saskatchewan (Anstey et al. 1995). Vesper Sparrows generally use both native and tame vegetation (Anstey et al. 1995, Prescott and Murphy 1996, Sutter and Brigham 1998, Davis and Duncan 1999). In Manitoba, however, numbers of Vesper Sparrows were negatively correlated with presence of native vegetation and positively correlated with presence of tame vegetation (Wilson and Belcher 1989). They inhabit edge habitats, such as fencerows between two crop fields and edges between cropland and woodland, as well as the cropland adjacent to edge (Berger 1968, Wiens 1969, Stewart 1975, Rodenhouse 1981, Faanes 1981, Rodenhouse and Best 1983, Perritt 1987, Perritt and Best 1989, Best et al. 1990). Vesper Sparrows frequently are observed in thickets, small trees and shrubs, wooded draws, fencerows containing trees or shrubs, and areas of coarse forbs or weeds (Maher 1974, Stewart 1975, Best 1983, Faanes 1983, Arnold and Higgins 1986, Prescott et al. 1995). Vesper Sparrows have been observed in colonies of white-tailed prairie dogs (Cynomys leucurus) (Clark et al. 1982).

In southern Wisconsin, Vesper Sparrows were not encountered in any wet habitat or in habitats with tall, dense vegetation (Sample 1989). Density of Vesper Sparrows was significantly higher in barrens and dry prairie than in oldfields, tame grasslands, small-grain fields, corn fields, mesic prairie, planted warm-season grasses, or hayland. Density was positively correlated with percent woody cover, total number of dead stems, low density of prostrate residual vegetation, percent bare ground, and proportion of plots that were burned. Density was negatively correlated with vegetation height/density and percent cover of standing residual vegetation. In Missouri, Vesper Sparrows used short cover (35\% cover at a height of 1 $\mathrm{cm}$ and $10 \%$ cover at a height of $25 \mathrm{~cm}$ ) found in a heavily grazed abandoned crop field; they were not observed within idle, grazed, hayed, or burned tallgrass (Skinner et al. 1984) .

In Wyoming, the availability of sagebrush for nest cover and song perches was important for Vesper Sparrows (Fautin 1975, Schaid et al. 1983). They occurred in areas dominated by sagebrush and were absent from areas where only grass and cactus (Opuntia) were present (Fautin 1975). In a study examining the relationship between vegetation and bird density in montane grassland, shrubsteppe, and tallgrass, mixed-grass, and shortgrass prairie in Colorado, Kansas, Montana, Nebraska, Oklahoma, Oregon, South Dakota, Texas, Washington, Wisconsin, and Wyoming, Vesper Sparrows occurred only in shrubsteppe and montane meadow habitats (Rotenberry and Wiens 1980). They were most abundant in montane meadow in Montana. Abundance was positively correlated with forb cover and the extent of variation in height of nearest forb or shrub. In Nevada and Oregon, abundance was significantly correlated with 
presence of green rabbitbrush (Chrysothamnus viscidiflorus), antelope bitterbrush (Purshia tridentata), and diversity of coverage in plant structural types (Wiens and Rotenberry 1981).

In Iowa, abundance of Vesper Sparrows in roadside vegetation was inversely related to height and vertical density of vegetation (Camp and Best 1993). Within alfalfa (Medicago sativa) fields, abundance appeared to be directly related to vegetation density until alfalfa reached a height of $30 \mathrm{~cm}$, at which time abundance became inversely related to vegetation height and density (Frawley and Best 1991).

Quality of territories and the number of pairs using cultivated areas may be affected by availability of elevated song perches (Berger 1968, Best and Rodenhouse 1984). Perches may be any structure or vegetation higher than the nesting substrate, such as dead herbaceous plants, sagebrush, shrubs, fences, or hay bales (Berger 1968; Wiens 1969; Schaid et al. 1983; Best and Rodenhouse 1984; D. G. McMaster, Saskatchewan Wetland Conservation Corporation, Regina, Saskatchewan, pers. comm.). In Iowa, presence of song perches was the most important characteristic of preferred territories (Rodenhouse 1981). During the pre-incubation period, males used shrubs, fence posts, and fence wire within fencerows as song perches (Rodenhouse 1981, Rodenhouse and Best 1983). During incubation, males sang from within crop fields, using clods of soil or tall pieces of crop residue as perches. During the nestling stage, males sang from one or two preferred perches. By early July, males used weeds within soybean fields or corn stalks in outer rows; corn stalks were taller than fence posts and shrubs within the fencerow. In Utah, big sagebrush (Artemisia tridentata) was used for perching more often than Utah juniper (Juniperus osteosperma), Utah serviceberry (Amelanchier utahensis), or buckbrush (Symphoricarpos orbiculatis), but other shrubs, primarily Utah juniper, were used significantly more than expected based on availability (Castrale 1983). Harrison (1977) provided artificial perches of two heights, 1.5 and $2.0 \mathrm{~m}$, to test whether birds preferred taller perch sites; Vesper Sparrows did not exhibit a preference for either height.

Nests are built on the ground and may be placed under dead stems, at the base of plants, near clods of soil, or near patches of bare ground where vegetation is sparse (Cameron 1908, Berger 1968). Nests may be found in dry upland prairie or in disturbed areas such as along dirt roads, in corn and alfalfa stubble, in hayland, and in grassed waterways within cropland (Roberts 1932, Berger 1968, Feist 1968, Schaid et al. 1983, Best and Rodenhouse 1984, Basore et al. 1986, Bryan and Best 1994, Camp and Best 1994, Faanes and Lingle 1995). In Montana, Vesper Sparrows nested under big sagebrush (Feist 1968, Best 1972).

Several master's theses and published studies have discussed nest location, territory characteristics, or abundance of Vesper Sparrows in agricultural settings in central Iowa. Rodenhouse (1981) studied habitat characteristics of territories encompassing fencerows that divided soybean fields and corn fields. Perritt (1987) examined the influences of weather on territory characteristics and breeding success and the relationship between habitat variables and territory size and quality. Her work also was conducted in areas where fencerows separated soybean and corn fields. Camp and Best $(1991,1994)$ focused on abundance and nest success of birds that nested in roadsides adjacent to rowcrop fields. Bryan and Best $(1991,1994)$ documented abundance and nest success of birds using grassed waterways in rowcrop fields. Waterways were in minimum-tillage corn or soybean fields. Most waterways were planted to smooth brome (Bromus inermis), were linear, and were connected to other forms of strip cover. Nest-site selection, nest success, and nesting density were compared between tilled fields and fields under no tillage (Basore et al. 1986). Gremaud (1983) examined the influences of litter cover; waste grain abundance; proximity of non-cultivated habitats, such as pasture and alfalfa 
hayfields; and the impact of farming practices (conventional tillage, no-tillage, minimum tillage, and organic farming) on nongame bird use of rowcrop fields. Stallman and Best (1996) examined use of a strip intercropping system by Vesper Sparrows. Further details from these authors' findings may be found in the appendix later in this account. A table near the end of the account lists the specific habitat characteristics for Vesper Sparrows by study.

\section{Area requirements:}

In Montana, average size of 60 territories was 1.65 ha (Reed 1986). Seven territories ranged in size from 0.29 to 3.04 ha (Reed 1985). In montane pasture in Montana, average territory size of three males was 1.96 ha (Wiens 1971). In southern Wisconsin, average size of five territories in dry areas with sparse vegetation was 0.88 ha (Wiens 1969). Average size of 42 territories located along fencerows between and adjacent to corn and soybean fields in Iowa was 2.3 ha; territories ranged in size from 1.8 to 3.2 ha (Rodenhouse 1981, Rodenhouse and Best 1983). Of 37 territories in corn and soybean fields in the same geographical location as Rodenhouse (1981), Perritt (1987) reported an average territory size of 3.05 ha one year and 3.57 ha another year. Size of territories ranged from 1.60 to 8.19 ha. Within a 5.6-ha uncultivated field in Michigan, Vesper Sparrows established from 8 to12 territories per yr over a period of 8 yr, with all available habitat occupied; average territory size per year varied from 0.48 to 0.72 ha (F. C. Evans, unpublished data, in Berger 1968: 869). In tallgrass prairie fragments in Illinois, Vesper Sparrows were encountered on small ( $<10 \mathrm{ha}$ ) sites but were not encountered on a single 650-ha site (Herkert 1991a,b). Abundance within burned prairie was not affected by area (Herkert 1994). In Maine, abundance of Vesper Sparrows was positively correlated with increasing area and habitat patchiness; Vesper Sparrows reached 50\% incidence at 20 ha in grassland barrens (Vickery et al. 1994).

No studies have investigated a relationship between patch size and Vesper Sparrow nest success or patch size and rates of brood parasitism by Brown-headed Cowbirds (Molothrus ater). In Saskatchewan, McMaster et al. (1999) examined the influence on nest success of several landscape features, including area of the study site, area of the study site (vegetation within study site was hayland) plus contiguous perennial grassland (referred to as the grass patch), grasspatch edge density, and grass-patch shape. None of the features significantly affected nest success. The authors also found that parasitized nests were closer to field edges than were unparasitized nests. Berger (1968) believed there was a relationship between parasitism and proximity to woody vegetation: in general, parasitized nests were in fields bordering woodlots or thickets, whereas non-parasitized nests were not near woody vegetation. In Colorado, Bock et al. (1999) compared the abundance of Vesper Sparrows between interior and edge locations. Edge was defined as the interface between suburban development and upland or lowland habitat, and interior locations were $200 \mathrm{~m}$ from edge. Vesper Sparrows were significantly more abundant on interior plots than on edge plots.

\section{Brown-headed Cowbird brood parasitism:}

The Vesper Sparrow is a fairly common host of the Brown-headed Cowbird and is known to rear cowbird young (Friedmann 1963). Parasitism rates vary from 0\% of 10 nests (Frawley 1989) to 61\% of 41 nests (Stallman and Best 1996). Refer to Table 1 in Shaffer et al. (2003) for rates of cowbird brood parasitism. In southern Saskatchewan, parasitized nests had smaller clutch sizes, hatched fewer eggs, fledged fewer host young per nest, and hatched fewer host young per successful nest than did unparasitized nests (McMaster et al. 1999). Parasitized nests 
were not significantly closer to perches or significantly less concealed than unparasitized nests. Multiple parasitism occasionally occurs; Cameron (1908) found a nest that contained three cowbird eggs and three host eggs.

\section{Breeding-season phenology and site fidelity:}

In Nebraska, Vesper Sparrows arrive on the breeding grounds from early March to late May and depart from mid-August to late November (Johnsgard 1980). In Iowa, Vesper Sparrows arrive from mid-March to mid-April and depart by mid-October (Rodenhouse and Best 1983, Kent and Dinsmore 1996). Females begin arriving within a week of the arrival of the first males. Vesper Sparrows arrive in Michigan in late March and depart from late October to early November (George 1952, Batts 1958). They arrive in Minnesota from late March to mid-May and depart from late August to late October (Berger 1968, Janssen 1987, Harrison 1974, Faanes 1981). They arrive in Montana in late April (Cameron 1908). In Saskatchewan, they arrive from mid-April to early May and depart from September to early October (Maher 1973, 1974; Knapton 1979). Peak breeding season in North Dakota is late May to mid-July (Stewart 1975).

Three studies in Michigan found that Vesper Sparrows may be double- or even triplebrooded. George (1952) reported one case of double-brooding. F. C. Evans (in Berger 1968:874) found that $45 \%$ of 29 females raised two broods and one female raised three broods. Harrison (1974) reported that breeding pairs in Michigan alfalfa fields were double-brooded. Renesting after initial clutch has been destroyed also has been recorded (George 1952).

Of 24 adults banded in Michigan, 46\% returned to the study area where they had been banded (George 1952). One pair mated for two consecutive breeding seasons. None of 45 banded nestlings were seen in subsequent breeding seasons. A male Vesper Sparrow returned to the same nesting territory for four consecutive years; for two of those years, he paired with the same banded mate (L. H. Walkinshaw in Berger 1968:878). Also in Michigan, a banded adult was recaptured $6 \mathrm{yr}$ later at the site where it was banded (Klimkiewicz and Futcher 1987). Of 26 male and 11 female Vesper Sparrows banded in Iowa, four males and two females returned to the same fencerows that they had used in the previous year (Best and Rodenhouse 1984). Two of the four returning males returned to the same territories they had occupied the previous year.

\section{Species' response to management:}

In Saskatchewan, density of Vesper Sparrows was higher in one mixed-grass prairie site 1 yr postburn and lower 2 and 3 yr postburn than in an unburned mixed-grass site (Pylypec 1991). Vesper Sparrows appeared on a restored prairie the third year after it was reseeded, which also was the year it was burned (Volkert 1992). They were most abundant 2 yr postburn and declined 3-5 yr postburn. In Iowa, Vesper Sparrows were more abundant in burned roadsides than in unburned roadsides (Camp and Best 1993). Abundance was inversely related to height and vertical density of vegetation in roadsides. In Illinois, Vesper Sparrows were most abundant in the first growing season postburn, were absent the second growing season postburn, and were uncommon the third growing season postburn (Herkert 1994). In Wyoming sagebrush, no significant differences were observed in the abundance of Vesper Sparrows among grazed areas that were burned 7-9 yr previous to the study, areas that were treated 20-22 yr previous to the study with 2,4-D to remove sagebrush, and areas that were untreated (Kerley and Anderson 1995). Also in Wyoming sagebrush, McGee (1976) reported that Vesper Sparrows used springburned areas 1-3 yr postburn and the unburned control. They occupied an area of sagebrush before it was burned in the fall, but were absent during 1-2 yr postburn growing seasons. In 
southeastern Idaho, Vesper Sparrows were present in sagebrush 3-4 yr postburn but were absent from the same area before it was burned and 1-2 yr postburn (Petersen and Best 1987). In Utah, density of Vesper Sparrows was similar between sagebrush areas that had been plowed and seeded to grasses $17 \mathrm{yr}$ before the study and areas that had been burned $4 \mathrm{yr}$ before the study (Castrale 1982). Vesper Sparrows were not present within areas in which sagebrush was removed by chaining, followed by seeding to grasses.

Within aspen parkland in Alberta, Vesper Sparrows were present in delayed-mowed hayfields and were absent from conventional hayland (Prescott et al. 1995). Delayed-mowed hayfields were planted to tame grasses and were cut once during the previous summer, after 15 July, whereas conventional hayfields were subject to conventional cutting regimes. In Saskatchewan, Vesper Sparrows were detected more often in tame hayland than in native pasture, tame pasture, or cropland (Anstey et al. 1995, Davis et al. 1997). In southern Saskatchewan hayfields, the number of pairs was not affected by amount of cropland or wetland within $1.6 \mathrm{~km}$ of study areas (McMaster et al. 1999). Nest success for both the incubation and nestling periods combined was not related to the proportion of wetland or cropland in study areas. In North Dakota, Vesper Sparrows avoided native hayland mowed the previous year (Kantrud 1981). In Iowa, Vesper Sparrows were six times more likely to nest in mowed grassed waterways than in unmowed grassed waterways (Bryan and Best 1994). However, they nested only in the longest waterways (>609 m), compared with waterways that were $60-304 \mathrm{~m}$ or 305$609 \mathrm{~m}$ long. The effects of mowing on Vesper Sparrows in alfalfa fields were examined by Frawley and Best (1991). Densities of birds were recorded before mowing, 2 wk after mowing, and 4 wk after mowing. Densities of Vesper Sparrows did not differ before and after mowing. In contrast, in Saskatchewan, clutch initiations were higher in late July and early August, after mowing, than in June, when hayland was unmowed and vegetation was thick and tall (McMaster et al. 1999). In southern Michigan, Vesper Sparrows nested in hayfields but avoided thick stands of hay (George 1952). Populations were not reduced markedly by mowing. Also in Michigan, Vesper Sparrows continued breeding activities following mowing of an alfalfa field in late June (Harrison 1974). Breeding was terminated after the second mowing in early August, but Vesper Sparrows may have successfully fledged young before the second mowing occurred.

The effects of burning, mowing, grazing, and idling on occurrence of birds were evaluated in southwestern Missouri; Vesper Sparrows were most common in a heavily grazed former crop field (Skinner et al. 1984). In Michigan, Vesper Sparrows avoided permanent pasture and pastures in hayfields (George 1952). In southwestern Wisconsin, Vesper Sparrows were more abundant in continuously grazed pastures than in rotationally grazed pastures or in ungrazed pastures (Temple et al. 1999). Ungrazed grasslands were neither mowed nor grazed from 15 May to 1 July. Continuously grazed sites were grazed throughout the summer at levels of 2.5-4 animals/ha. Rotationally grazed pastures, stocked with 40-60 animals/ha, were grazed for 1-2 d and then left undisturbed for 10-15 d before being grazed again; pastures averaged 5 ha. All sites were composed of 50-75\% cool-season grasses, 7-27\% legumes, and 8-23\% forbs. In aspen parkland in southern Alberta, Vesper Sparrows occurred in low numbers in early-season tame pastures (grazed from late April to mid-June), early-season native pastures (grazed in early summer), and deferred-grazed native pastures (grazed after 15 July), and were not present in continuously grazed native pastures (Prescott and Wagner 1996). In aspen parkland in central Alberta, Vesper Sparrows were common in both native and tame pasture (Prescott and Murphy 1996). They were found in native pasture on areas with moderate cover diversity and with uniformly short grass. In tame pasture, they used areas with moderate amounts of herbaceous 
biomass, moderate to low variation in herbaceous height, and moderate to high proportion of forbs relative to grasses. In Saskatchewan, no significant difference in abundance of Vesper Sparrows was detected between lightly grazed mixed-grass prairie and lightly grazed crested wheatgrass (Agropyron cristatum) (Sutter and Brigham 1998). Vesper Sparrows were equally frequent in native pastures as in three types of tame pastures (Davis and Duncan 1999). The three types were pure stands of crested wheatgrass; mixed stands of crested wheatgrass, smooth brome, and bluegrass (Poa spp.); and stands of crested wheatgrass and alfalfa. Occurrence was negatively associated with vegetation height and clubmoss (Selaginella densa). Vesper Sparrows were detected as frequently in native mixed-grass pasture as in tame pasture (Anstey et al. 1995, Davis et al. 1997). Anstey et al. (1995) found that abundance in mixed-grass pasture was positively associated with forbs and broad-leaved grasses $\leq 10 \mathrm{~cm}$ tall and with shrubs 20 $100 \mathrm{~cm}$ tall; abundance was negatively associated with broad-leaved grasses 20-100 cm tall. Frequency of occurrence of Vesper Sparrows in native pasture was unaffected by grazing intensity. Heavy grazing was characterized by the removal of virtually all litter and plant material, coverages of $>20 \%$ bare soil and $>40 \%$ clubmoss, and the presence of small plants with poor vigor. Light grazing was characterized by little or no evidence of grazing, coverages of $<10 \%$ bare soil and $<10 \%$ clubmoss, and the presence of robust and vigorous plants, abundant litter, and plant material. Moderately grazed pastures had characteristics intermediate between the other two types. In aspen parkland, Vesper Sparrows were most abundant in deferred-grazed tame and native grasslands, followed by idle native grassland, continuously grazed native grassland, delayed-mowed hayfields, brush/shrub, idle tame grassland, tame pasture, continuously grazed native parkland, tame DNC, and idle native parkland (Prescott et al. 1995). They did not occur in idle deciduous upland, conventional hayfields, cropland, native DNC, shelterbelts, or saline or fresh wetlands.

The effects of grazing on short- and mixed-grass prairie and shrubsteppe were examined in Colorado, Montana, Nebraska, North Dakota, South Dakota, and Wyoming (Kantrud and Kologiski 1982, 1983). Densities of Vesper Sparrows were highest on moderately grazed borollic aridisols (characterized by $20 \mathrm{~cm}$ average vegetation height and 17\% bare soil) and lightly grazed ustic aridisols (characterized by $23 \mathrm{~cm}$ average vegetation height and 9\% bare soil), located in shrubsteppe/grassland habitat. They were least common on typic and aridic ustolls, regardless of grazing intensity. Areas with highest densities of Vesper Sparrows also had above-average abundance of wheatgrasses (Agropyron spp.), Junegrass (Koeleria pyramidata), fringed sagewort (Artemisia frigida), and big sagebrush.

Vesper Sparrows are not common in planted cover (Johnson and Schwartz 1993, Prescott et al. 1995, Best et al. 1997). In Iowa, Vesper Sparrows were more common in rowcrops than in CRP, although they nested in both habitats (Patterson 1994). Best et al. (1997) reported that Vesper Sparrows were uncommon in CRP in Indiana, Iowa, and Michigan and were not encountered in Kansas, Missouri, or Nebraska. They were abundant and frequently nested in rowcrops. In Minnesota, Montana, North Dakota, and South Dakota, Vesper Sparrows were more common in cropland than in CRP (Johnson and Schwartz 1993, Johnson and Igl 1995). In eastcentral Saskatchewan, Vesper Sparrows were present in DNC as well as in idle native grasslands and wheat fields (Hartley 1994a,b). Dale (1993) reported that Vesper Sparrows were uncommon in tame DNC, fairly common in low nesting cover of creeping red fescue (Festuca rubra) and Kentucky bluegrass (Poa pratensis), and absent from fallow cropland. Also in Saskatchewan, Vesper Sparrows were more abundant in cropland on organic farmland than on conventional or minimum-tillage farmland or in DNC (Shutler et al. 2000). Presence of Vesper 
Sparrows was negatively related to number of wetlands within $2.8 \mathrm{~km}^{2}$ of point counts. Vesper Sparrows were observed in wetlands or wetland margins within all farmland types and within DNC; presence was positively related to percent woody vegetation around wetland margin. In Alberta, Vesper Sparrows were present in low abundance on 1-, 3-, and 4-yr-old tame DNC but were not present in native DNC or cropland (Prescott et al. 1995, Prescott and Murphy 1999). In Manitoba, Vesper Sparrows were present in idle mixed-grass prairie but were not present in DNC planted to native species or to tame species (Dhol et al. 1994). In contrast to the above findings, Vesper Sparrows in southern Canada occurred significantly more frequently in PCP than in cropland (McMaster and Davis 1998). PCP is a Canadian program that pays farmers to seed highly erodible land to perennial grassland cover; it differs from CRP in the United States in that haying and grazing are allowed annually in PCP. Presence of Vesper Sparrows was influenced by the amount of grassland surrounding PCP sites; frequency of occurrence was higher in sites surrounded more by grasslands than by sites surrounded by cropland, wetland, woodland, or human settlement. There was no significant difference in frequency of occurrence between PCP sites that were hayed and those that were grazed.

Although Vesper Sparrows nest in cropland (Rodenhouse and Best 1983, Patterson and Best 1996, Best et al. 1997), nesting success may be low. Rodenhouse and Best (1983) found that only $29 \%$ of 45 nests in Iowa rowcrops were successful. The first nests of the breeding season were destroyed by seedbed preparation or planting. About $50 \%$ of nests built later in the breeding season, when nests were placed in rowcrops, were destroyed by other mechanical operations. Only $2 \%$ of 41 nests was successful in Iowa fields where strip intercropping (i.e., planting rowcrops, legumes, and small grains in a series of adjacent, narrow strips) was used (Stallman and Best 1996). No active nests survived mechanical field operations. Based on roadside censuses in Alberta, Vesper Sparrows were significantly more common at census stops where land use was a mix of cultivation and grazed pastures than at grazed or undisturbed (i.e., where mowing, grazing, or cultivation did not occur) stops; they also were significantly more common at grazed stops than at undisturbed stops (Owens and Myres 1973). In Iowa, nest densities were higher in no-tillage corn and soybean fields and in strip cover than in corn fields that were tilled (Basore et al. 1986). Although tillage does not always lead to nest destruction, nest losses were primarily from agricultural operations or from depredation (Rodenhouse 1981, Best and Rodenhouse 1984). Rodenhouse and Best (1983) suggested that adoption of no-tillage practices would enhance Vesper Sparrow production because a decrease in tillage operations would decrease the number of nests destroyed by tillage. Furthermore, retention of crop residue on fields would increase nesting success by affecting nest placement and/or concealment. The authors also suggested that fencerow removal would reduce the use of corn and soybean fields by Vesper Sparrows. Densities of breeding Vesper Sparrows possibly could be increased by increasing the proportion of herbaceous-shrubby fencerows in a section. Best and Hill (1983) found that Vesper Sparrows inhabited fencerows that contained only herbaceous vegetation, fencerows of scattered trees and shrubs, or fencerows of continuous trees and shrubs. In a comparison of nesting activity in minimum-tillage, conventional tillage, and organic farms in North Dakota, Vesper Sparrows mainly used conventionally tilled fields; conventional was defined as involving fall and spring tillage and pesticides (Lokemoen and Beiser 1997).

The effects of grasshopper (Orthoptera) control methods (malathion, carbaryl, and Nosema locustae bait, a biological control agent for grasshoppers) on Vesper Sparrow density were evaluated in Colorado, Idaho, North Dakota, Utah, and Wyoming (George et al. 1995). Density did not decline 10 and $21 \mathrm{~d}$ after treatment (all treatments combined). In North Dakota, 
brain levels of acetylcholinesterase (AChe) in Vesper Sparrows did not differ between areas treated with carbaryl bait and untreated areas (George et al. 1992). Carbaryl is an ACheinhibiting chemical. In Montana and Wyoming, numbers of Vesper Sparrows did not decline significantly from application rates of 140, 210, or $280 \mathrm{~g} /$ ha of BAYGON* ${ }^{*}$ (o-isopropoxyphenyl methylcarbamate; McEwen et al. 1972). Numbers of Vesper Sparrows did decline significantly on areas in Montana sprayed with 441 and $672 \mathrm{~g} /$ ha applications of fenitrothion. In sagebrush/grassland habitat of Montana, the effect of various degrees of sagebrush removal on Vesper Sparrow abundance was examined (Best 1972). Sagebrush was killed by aerial spraying with 2,4-D. The five treatments involved areas that were rendered devoid of live sagebrush, areas in which sagebrush was killed only in alternate strips $30.48 \mathrm{~m}$ wide (strip spray), areas in which sagebrush was only partially killed (partial spray), a control (no spraying), and a control in which grazing occurred. Both strip spray and partial spray reduced live sagebrush by about $50 \%$. The biggest change in abundance of Vesper Sparrows occurred on the grazed control plot, where numbers of breeding Vesper Sparrows dropped 30\% (from 25 birds to 17.5 birds) in 2 yr. Indirect effects of spraying on abundance of Vesper Sparrows were not obvious. Dominant plant and animal species consumed by Vesper Sparrows were similar between sprayed and unsprayed areas, but the amount of those species consumed between sprayed and unsprayed areas differed.

In Wyoming shrubsteppe, there was no significant difference in the mean number of Vesper Sparrows among areas that were treated with 2,4-D 20-22 yr before the study and that were grazed at the time of the study compared with areas that were unsprayed and also grazed, and areas that were burned 7-9 yr earlier and grazed (Kerley and Anderson 1995). Grazing intensity was higher on herbicide-treated plots than on untreated plots and higher on burned than on untreated plots. Grazing intensity was not different between herbicide-treated plots and burned plots. In a Texas study examining the effects on avian density of discing, spraying of 2,4,5-T about 14 yr prior to the study, and construction of brush shelters, grassland sparrows, as a group, were more abundant in the treated than untreated areas; effects on particular species, such as Vesper Sparrow, composing the group of grassland sparrows, were not examined (Gruver and Guthery 1986). In Ontario corn fields, the mean number of Vesper Sparrows did not differ between pre- and post-applications of the granular insecticides fonofos and terbufos, which are used to control corn rootworm (Diabrotica spp.), or between treated fields and control fields (Knapton and Mineau 1995).

The effects of mine reclamation on densities of breeding Vesper Sparrows were examined in South Dakota and Wyoming (Schaid et al. 1983). A single unmined area of grass and big sagebrush was selected as a control. Dominant native grass species were western wheatgrass (Pascopyrum smithii), Junegrass, buffalo grass (Buchloe dactyloides), and blue grama (Bouteloua gracilis). Bluegrass, brome grass (Bromus spp.), green needlegrass (Stipa viridula), and foxtail barley (Hordeum jubatum) also were widespread on the area. Treatments were unreclaimed bentonite clay spoils and reclaimed mine areas. The unreclaimed area consisted of numerous bentonite spoils and mine pits with remnants of unmined grass/sagebrush habitat between the spoils and pits. Reclaimed areas had been recontoured and revegetated mostly with native grasses (green needlegrass and wheatgrasses [Agropyron spp.]) although

*References to chemical trade names does not imply endorsement of commercial products by the Federal Government. 
some areas were planted to crested wheatgrass. Reclamation occurred 3-10 yr prior to the study. No remnants of the original grass/sagebrush habitat existed on the reclaimed area. Vesper Sparrows were among the most common breeding species in the grass/sagebrush area. Vesper Sparrow density was significantly greater on the control than on the two mining treatments, and density was similar between the two mined treatments. Lack of sagebrush in the mined treatments may have accounted for lower density of Vesper Sparrows. The authors speculated that Vesper Sparrows that did occur in reclaimed spoil areas probably were attracted to the seed of green needlegrass for food.

In Colorado, the influence of recreational trails on avian abundance was evaluated in mixed-grass prairie (Miller et al. 1998). Vesper Sparrows were significantly more abundant along control transects, which were placed in blocks of mixed-grass prairie without trails, than along trails. In a Saskatchewan study that examined whether the abundance of grassland birds differed between roadsides and trailsides, abundance of Vesper Sparrows was significantly higher along roadsides than along trailsides (Sutter et al. 2000). Roads were defined as traveling surfaces with adjacent drainage ditches planted to smooth brome and ending with a fence 11-18 $\mathrm{m}$ from the traveling surface. Trails were defined as a single pair of wheel ruts visually indistinct from surrounding habitat in terms of plant structure and composition. Habitat along roads and trails were parcels of lightly to moderately grazed native prairie $>256$ ha.

\section{Management Recommendations:}

If sagebrush must be controlled by burning or chaining, do so in the spring before breeding territories are established or in late summer or early fall after birds have left the area (Castrale 1982). Treat large areas in small blocks over several years. Leave some sagebrush to serve as perches.

Burn or mow roadsides every 3-5 yr to maintain vegetation quality (Camp and Best 1993). To reduce nest losses, mow roadsides only in early spring or late summer (Camp and Best 1994). Encourage farmers to retain fence lines along roadsides, especially in areas where forbs are sparse, to serve as perches (Camp and Best 1993, 1994).

Delay spraying pesticides and mowing in CRP until after July to avoid the peak nesting period (Patterson 1994).

Delay mowing grassed waterways in cropfields until late August to avoid disturbing nesting birds (Bryan and Best 1994). Waterways may serve as refuges because other haylands are mowed earlier in the season. Mow every 3-4 yr to maintain grass vigor. Do not burn waterways in the fall. Burning would have to be delayed until after fall harvest, which would preclude any regrowth of the vegetation. Encourage the growth of forbs in waterways.

Maintain fencerows adjacent to cropland (Rodenhouse and Best 1983). Removal may reduce the use of corn and soybean fields by Vesper Sparrows. Near cropland, increase the proportion of fencerows that consist of both herbaceous and shrubby vegetation (Rodenhouse 1981, Rodenhouse and Best 1983). 
To increase productivity of Vesper Sparrows in crop fields, leave more corn residue and reduce the number of mechanical field operations (Rodenhouse 1981). Low nesting success early in the breeding season was mostly attributed to nest destruction by mechanical field operations such as seedbed preparation with a rotary hoe or cultivation. Adopt no-tillage practices to enhance Vesper Sparrow productivity (Rodenhouse and Best 1983). A decrease in tillage operations would decrease the number of nests destroyed by tillage. Retention of crop residue on fields may increase nesting success by providing more nest concealment cover.

Reduced-tillage farming provides more foraging opportunities than conventional-tillage methods (Rodenhouse and Best 1994). Use no-tillage or minimum-tillage methods to retain crop residue and waste grain on the surface of fields for birds to use (Gremaud 1983). However, the use of herbicides in no-tillage or minimum-tillage practices decreases weed-seed density.

If a system of strip intercropping must be used, decrease the number of passes made by farm machinery through strips or increase time between passes to $3.5 \mathrm{wk}$ to allow the completion of nesting cycles (Stallman and Best 1996). As an alternative to mechanical means of weed control, apply herbicides minimally by spot spraying.

Limit pesticide use in areas where Vesper Sparrows forage (Rodenhouse and Best 1994). Use only rapidly degrading chemicals of low toxicity at the lowest rates possible (McEwen et al. 1972). Avoid pest outbreaks by maintaining range in good condition. Overgrazed and droughtaffected areas tend to be more prone to insect outbreaks.

Plant shrubs on recontoured and reseeded strip mines to make reclaimed areas more attractive to Vesper Sparrows (Schaid et al. 1983). To facilitate the expansion of shrubby areas, maintain areas of shrubs along roadsides, between mine spoils, and around equipment and storage buildings during mining and reclamation operations. 
Table. Vesper Sparrow habitat characteristics.

\begin{tabular}{|c|c|c|c|}
\hline Author(s) & Location(s) & Habitat(s) Studied ${ }^{*}$ & Species-specific Habitat Characteristics \\
\hline Anstey et al. 1995 & Saskatchewan & $\begin{array}{l}\text { Cropland, mixed-grass } \\
\text { pasture, tame hayland, } \\
\text { tame pasture }\end{array}$ & $\begin{array}{l}\text { Were detected most often in parkland fringe grassland and } \\
\text { equally frequently in native pasture as in tame pasture; were } \\
\text { detected less frequently in cropland than in hayland and } \\
\text { more frequently in hayland than in native or tame pasture; } \\
\text { frequency of occurrence was unaffected by grazing } \\
\text { intensity; abundance was positively associated with forbs } \\
\text { and broad-leaved grasses } \leq 10 \mathrm{~cm} \text { tall and with shrubs } 20 \text { - } \\
100 \mathrm{~cm} \text { tall; abundance was negatively associated with } \\
\text { broad-leaved grasses } 20-100 \mathrm{~cm} \text { tall }\end{array}$ \\
\hline Arnold and Higgins 1986 & North Dakota & $\begin{array}{l}\text { Mixed-grass hayland, } \\
\text { mixed-grass pasture }\end{array}$ & $\begin{array}{l}\text { Were found in shrubby transects of western snowberry } \\
\text { (Symphoricarpos occidentalis) and silverberry (Elaeagnus } \\
\text { commutata) }\end{array}$ \\
\hline Basore et al. 1986 & Iowa & Cropland, idle & $\begin{array}{l}\text { Nested in corn planted into sod residue (former pasture or } \\
\text { hayland), corn planted into corn residue, soybeans planted } \\
\text { into corn residue, tilled corn, and strip cover; nest densities } \\
\text { were higher in strip cover than in no-tillage corn; in no- } \\
\text { tillage fields, nest sites were in areas with less residue than } \\
\text { that found in the field overall }\end{array}$ \\
\hline Berger 1968 & Rangewide & Cropland, woodland & $\begin{array}{l}\text { Used extensive cultivated tracts, such as those planted to } \\
\text { hay, wheat, or corn; favorite song perches near woods were } \\
\text { branches } \geq 7.6 \mathrm{~m} \text { above ground along the edge of the } \\
\text { woods; in treeless areas, perches were dead weeds, fences, } \\
\text { shrubs, or any structure or vegetation higher than nesting } \\
\text { substrate; nested on the ground, near patches of bare } \\
\text { ground, or where vegetation was short and sparse; nests } \\
\text { were placed at the base of plants, near dirt clods, or under } \\
\text { prostrate, dead stems }\end{array}$ \\
\hline
\end{tabular}




\begin{tabular}{|c|c|c|c|}
\hline Best 1972 & Montana & $\begin{array}{l}\text { Shortgrass pasture, } \\
\text { shrubsteppe }\end{array}$ & $\begin{array}{l}\text { Nested on the ground beneath relatively short ( } 14 \text { to } 34.3 \\
\text { cm in height) big sagebrush (Artemisia tridentata) plants, } \\
\text { which averaged } 0.033 \mathrm{~m}^{3} \text { in volume when alive, } 0.033 \mathrm{~m}^{3} \\
\text { when partially dead, and } 0.024 \mathrm{~m}^{3} \text { when completely dead; } \\
\text { grass concealment of nests was greater at nest sites where } \\
\text { sagebrush was dead, either because Vesper Sparrows } \\
\text { preferred this or because there was an overall increase in } \\
\text { grass coverage in sprayed areas; grass species associated } \\
\text { with sagebrush were western wheatgrass (Pascopyrum } \\
\text { smithii), bluebunch wheatgrass (Pseudoroegneria spicata), } \\
\text { green needlegrass (Stipa viridula), and Junegrass (Koeleria } \\
\text { cristata) }\end{array}$ \\
\hline Best 1983 & Iowa & Cropland, idle & $\begin{array}{l}\text { Were abundant during spring and summer in herbaceous } \\
\text { fencerows, in fencerows with scattered trees or shrubs, and } \\
\text { in fencerows of continuous trees or shrubs }\end{array}$ \\
\hline Best et al. 1997 & $\begin{array}{l}\text { Indiana, Iowa, } \\
\text { Kansas, } \\
\text { Michigan, } \\
\text { Missouri, } \\
\text { Nebraska }\end{array}$ & $\begin{array}{l}\text { Conservation Reserve } \\
\text { Program (CRP; } \\
\text { burned seeded-native, } \\
\text { burned seeded- } \\
\text { native/tame; burned } \\
\text { tame, idle seeded- } \\
\text { native, idle seeded- } \\
\text { native/tame, idle tame, } \\
\text { seeded-native/tame } \\
\text { hayland, tame } \\
\text { hayland), cropland } \\
\end{array}$ & $\begin{array}{l}\text { Frequently nested in rowcrops; were present in CRP in low } \\
\text { abundances }\end{array}$ \\
\hline Best and Hill 1983 & Iowa & Cropland & $\begin{array}{l}\text { Occurred in all types of fencerows (fencerows containing } \\
\text { herbaceous vegetation, scattered trees and shrubs, or } \\
\text { continuous trees and shrubs); found in cropland areas }\end{array}$ \\
\hline Best and Rodenhouse & Iowa & Cropland, idle & $\begin{array}{l}\text { Territories occurred along fencerows and extended no more } \\
\text { than } 80 \mathrm{~m} \text { into the crop field on both sides of the fencerow; }\end{array}$ \\
\hline
\end{tabular}




\begin{tabular}{|c|c|c|c|}
\hline 1984 & & & $\begin{array}{l}\text { pairing success was significantly related to the number of } \\
\text { shrub groups and the amount of crop residue within } \\
\text { territories; elevated perches enhanced territory preference } \\
\text { and affected territory location }\end{array}$ \\
\hline Best et al. 1990 & Illinois, Iowa & $\begin{array}{l}\text { Cropland, edge, idle, } \\
\text { idle tame, woodland }\end{array}$ & $\begin{array}{l}\text { Were observed in corn fields, woodland/cropland edge, and } \\
\text { grassland/cropland edge }\end{array}$ \\
\hline Bock et al. 1999 & Colorado & $\begin{array}{l}\text { Idle mixed-grass, idle } \\
\text { tallgrass, mixed-grass } \\
\text { pasture, tallgrass } \\
\text { pasture, tame hayland }\end{array}$ & $\begin{array}{l}\text { Were more abundant on interior plots than on edge plots } \\
\text { and in upland habitat than in lowland habitat; edge was } \\
\text { defined as the interface between suburban development and } \\
\text { upland or lowland habitat, and interior locations were } 200 \\
\text { m from edge; upland grasslands were mixed-grass prairie } \\
\text { and lowland grasslands were tallgrass prairie or tame } \\
\text { hayland }\end{array}$ \\
\hline $\begin{array}{l}\text { Bryan and Best 1991, } \\
1994\end{array}$ & Iowa & $\begin{array}{l}\text { Cropland, idle tame, } \\
\text { tame hayland }\end{array}$ & $\begin{array}{l}\text { Were commonly observed in cropland; nests were found in } \\
\text { grassed waterways; nested only in the longest }(>609 \mathrm{~m}) \\
\text { waterways compared to shorter (60-304 m and } 305-609 \mathrm{~m}) \\
\text { waterways; occurrence of nests was six times more likely in } \\
\text { completely mowed grassed waterways than unmowed } \\
\text { grassed waterways }\end{array}$ \\
\hline Cameron 1908 & Montana & $\begin{array}{l}\text { Idle shortgrass, idle } \\
\text { shrubsteppe }\end{array}$ & Nested among sagebrush \\
\hline Camp and Best 1993 & Iowa & $\begin{array}{l}\text { Burned seeded-native } \\
\text { tallgrass/tame, burned } \\
\text { tame, cropland, idle } \\
\text { seeded-native } \\
\text { tallgrass/tame, idle } \\
\text { tame }\end{array}$ & $\begin{array}{l}\text { Were commonly observed along roadsides and in rowcrops; } \\
\text { were more abundant in burned than unburned roadsides; } \\
\text { abundance was inversely related to height and vertical } \\
\text { density of vegetation in roadsides }\end{array}$ \\
\hline Camp and Best 1994 & Iowa & $\begin{array}{l}\text { Burned seeded-native } \\
\text { tallgrass/tame, burned }\end{array}$ & $\begin{array}{l}\text { Nested in short, roadside vegetation; nest density was } \\
\text { positively correlated with amount of bare ground and }\end{array}$ \\
\hline
\end{tabular}




\begin{tabular}{|c|c|c|c|}
\hline & & $\begin{array}{l}\text { tame, cropland, idle } \\
\text { seeded-native } \\
\text { tallgrass/tame, idle } \\
\text { tame }\end{array}$ & $\begin{array}{l}\text { negatively correlated with vegetation height and a } \\
\text { vegetation vertical density index; vegetation at nest sites } \\
\text { averaged } 4.1 \text { vertical density, } 32.5 \mathrm{~cm} \text { maximum height, } \\
52.1 \% \text { grass cover, } 13.3 \% \text { forb cover and } 31.2 \% \text { bare } \\
\text { ground; vegetation } 1 \mathrm{~m} \text { from nest sites averaged } 5.1 \text { vertical } \\
\text { density, } 20.7 \mathrm{~cm} \text { maximum height, } 40.0 \% \text { grass cover, } 3.2 \% \\
\text { forb cover, and } 55.0 \% \text { bare ground; most nests were located } \\
\text { on the foreslope (defined as the slope of the roadside } \\
\text { between the road and the bottom of the ditch) where } \\
\text { mowing and gravel kept the vegetation short }\end{array}$ \\
\hline Castrale 1982 & Utah & Shrubsteppe & $\begin{array}{l}\text { Average values of characteristics of nest sites in sagebrush } \\
\text { (Artemisia)/grassland sites were } 0 \mathrm{~cm} \text { nest height, } 49 \mathrm{~cm} \\
\text { shrub height, } 233 \mathrm{~cm}^{2} \text { shrub cover, } 208 \mathrm{~cm}^{3} \text { shrub volume, } \\
\text { and } 4767 \text { shrubs/ha }\end{array}$ \\
\hline Castrale 1983 & Utah & Shrubsteppe & $\begin{array}{l}\text { Perched primarily on big sagebrush but Utah juniper } \\
\text { (Juniperus osteosperma) was used significantly more than } \\
\text { expected based on availability; also perched on forbs and } \\
\text { fences; average measurements of perch sites based on } 86 \\
\text { perches were } 101.2 \mathrm{~cm} \text { perch height, } 928 \mathrm{~cm}^{2} \text { perch cover, } \\
3778 \mathrm{~cm}^{2} \text { volume, } 143.1 \mathrm{~cm} \text { intershrub distance, and } 11.9 \\
\text { shrubs/30 } \mathrm{m}^{2} \text { (density based on sample size of } 73 \text { ); height } \\
\text { and cover of song perches were significantly higher than } \\
\text { nearest shrubs; no preference was exhibited for live over } \\
\text { dead shrubs }\end{array}$ \\
\hline Clark et al. 1982 & $\begin{array}{l}\text { Colorado, New } \\
\text { Mexico, Utah }\end{array}$ & $\begin{array}{l}\text { Colonies of burrowing } \\
\text { mammals, idle } \\
\text { shortgrass }\end{array}$ & $\begin{array}{l}\text { Were present on white-tailed prairie dog (Cynomus } \\
\text { leucurus) towns }\end{array}$ \\
\hline Dale 1984 & Saskatchewan & $\begin{array}{l}\text { Idle mixed-grass, } \\
\text { mixed-grass pasture }\end{array}$ & $\begin{array}{l}\text { Were uncommon on grazed as well as on ungrazed } \\
\text { grassland }\end{array}$ \\
\hline Dale 1993 & Saskatchewan & Dense nesting cover & Were common in short grass, uncommon in DNC, and \\
\hline
\end{tabular}




\begin{tabular}{|c|c|c|c|}
\hline & & $\begin{array}{l}\text { (DNC; idle tame), } \\
\text { idle, low nesting } \\
\text { cover: idle tame }\end{array}$ & absent from fallow cropland \\
\hline Davis and Duncan 1999 & Saskatchewan & $\begin{array}{l}\text { Mixed-grass pasture, } \\
\text { tame pasture }\end{array}$ & $\begin{array}{l}\text { Were equally frequent in native pastures as in tame } \\
\text { pastures; occurrence was negatively associated with } \\
\text { vegetation height and clubmoss (Selaginella densa) }\end{array}$ \\
\hline Davis et al. 1997 & Saskatchewan & $\begin{array}{l}\text { Cropland, hayland, } \\
\text { mixed-grass pasture, } \\
\text { tame pasture }\end{array}$ & $\begin{array}{l}\text { Were most abundant in hayland and least abundant in } \\
\text { cropland; found in equal abundance in tame pastures and in } \\
\text { native pastures }\end{array}$ \\
\hline Dhol et al. 1994 & Manitoba & $\begin{array}{l}\text { DNC (idle seeded- } \\
\text { native, idle tame), idle } \\
\text { mixed-grass }\end{array}$ & $\begin{array}{l}\text { Found only in idle native grasslands; absent from both } \\
\text { native and tame DNC }\end{array}$ \\
\hline Emmerich 1978 & South Dakota & Woodland & $\begin{array}{l}\text { Were found in tree claims (nonlinear plantings of trees } \geq 2.1 \\
\text { ha not planted in rows) and single-row windbreaks (single } \\
\text { row of shrubs and/or trees that were at least } 2 \mathrm{~m} \text { tall and } \\
100 \mathrm{~m} \text { long); were not found in riparian woodlands } \\
\text { (woodlands were } \geq 20 \mathrm{~m} \text { wide and were } \geq 250 \mathrm{~m} \text { long along } \\
\text { the shore of a permanent stream); tree claims were dense } \\
\text { stands of trees, ungrazed to heavily grazed, with a sparse to } \\
\text { dense shrub layer, and many dead trees; single-row } \\
\text { windbreaks ranged from young, shrub-height trees to } \\
\text { mature trees with a scant to dense shrub understory }\end{array}$ \\
\hline Faanes 1981 & $\begin{array}{l}\text { Minnesota, } \\
\text { Wisconsin }\end{array}$ & $\begin{array}{l}\text { Cropland, idle, idle } \\
\text { tallgrass/tame, shrub } \\
\text { carr, tame hayland, } \\
\text { tame pasture, wet } \\
\text { meadow, wetland, } \\
\text { woodland }\end{array}$ & $\begin{array}{l}\text { Used edge habitats such as fencerows along agricultural } \\
\text { fields and retired cropland near woodland; used highway } \\
\text { rights-of-way, oldfields, brushy areas, and occasionally jack } \\
\text { pine (Pinus banksiana) barrens }\end{array}$ \\
\hline Faanes 1983 & North Dakota & Idle mixed-grass, & Commonly nested in wooded draws and upland native \\
\hline
\end{tabular}




\begin{tabular}{|c|c|c|c|}
\hline & & $\begin{array}{l}\text { mixed-grass pasture, } \\
\text { woodland }\end{array}$ & prairie \\
\hline Faanes and Lingle 1995 & Nebraska & $\begin{array}{l}\text { Cropland, idle mixed- } \\
\text { grass, idle shortgrass, } \\
\text { idle tallgrass, pasture, } \\
\text { tame hayland, wet } \\
\text { meadow, wetland, } \\
\text { woodland }\end{array}$ & Nested in domestic hayland and upland prairie \\
\hline Fautin 1975 & Wyoming & Shrubsteppe & $\begin{array}{l}\text { Occurred in areas where sagebrush was present but not in } \\
\text { areas with only grass and cactus (Opuntia) }\end{array}$ \\
\hline Feist 1968 & Montana & $\begin{array}{l}\text { Sagebrush, shortgrass } \\
\text { pasture }\end{array}$ & $\begin{array}{l}\text { Nested on the ground under big sagebrush; average height } \\
\text { of big sagebrush at } 11 \text { nest sites was } 32.8 \mathrm{~cm} \text { with a range } \\
\text { from } 15 \text { to } 41 \mathrm{~cm} \text {; percent canopy coverage averaged } 14.5 \% \\
\text { with a range from } 3 \text { to } 32 \% \text {; plants with the highest } \\
\text { coverage and percent frequency of occurrence around nests } \\
\text { were western wheatgrass, bluebunch wheatgrass, and blue } \\
\text { grama (Bouteloua gracilis); frequency of occurrence of } \\
\text { bare ground ranged from } 98 \text { to100\% and coverage ranged } \\
\text { from } 16 \text { to } 48 \%\end{array}$ \\
\hline Finzel 1964 & Wyoming & $\begin{array}{l}\text { Mixed-grass pasture, } \\
\text { shortgrass pasture, } \\
\text { woodland }\end{array}$ & Used grassland/conifer transition area \\
\hline $\begin{array}{l}\text { Frawley 1989, Frawley } \\
\text { and Best } 1991\end{array}$ & Iowa & Tame hayland & $\begin{array}{l}\text { Occurred at low densities both before and after mowing; } \\
\text { abundance appeared to be positively related to vegetation } \\
\text { density until alfalfa (Medicago sativa) reached } 30 \mathrm{~cm} \text { tall, } \\
\text { at which time abundance became inversely related to } \\
\text { vegetation height and density; average measurements in } \\
\text { territories before mowing were } 16 \% \text { bare ground, } 12 \% \\
\text { grass coverage, } 75 \% \text { forb coverage, and average height of }\end{array}$ \\
\hline
\end{tabular}




\begin{tabular}{|c|c|c|c|}
\hline & & & $\begin{array}{l}49 \mathrm{~cm} \text {; average measurements before second mowing were } \\
14 \% \text { bare ground, } 11 \% \text { grass coverage, } 76 \% \text { forb coverage, } \\
\text { and average height of } 44 \mathrm{~cm}\end{array}$ \\
\hline George 1952 & Michigan & $\begin{array}{l}\text { Cropland, hayland, } \\
\text { pasture, woodland } \\
\text { edge }\end{array}$ & $\begin{array}{l}\text { Nested in hayfields, avoided permanent pasture and } \\
\text { hayfield pasture, which was apparently too barren; avoided } \\
\text { thick hayland; populations were not reduced markedly by } \\
\text { mowing }\end{array}$ \\
\hline Graber and Graber 1963 & Illinois & $\begin{array}{l}\text { Cropland, hayland, } \\
\text { idle, tame pasture, } \\
\text { wetland, woodland }\end{array}$ & $\begin{array}{l}\text { Were observed in all grassland and hay habitats; fallow, } \\
\text { small-grain, soybean, corn, and plowed fields; shrubbery of } \\
\text { all types; and orchards; highest densities were in shrubby } \\
\text { areas of fencerows and roadsides and in red clover } \\
\text { (Trifolium pratense) fields }\end{array}$ \\
\hline Gremaud 1983 & Iowa & $\begin{array}{l}\text { Cropland, tame } \\
\text { hayland, tame pasture, } \\
\text { woodland }\end{array}$ & $\begin{array}{l}\text { No significant difference in abundance between rowcrop } \\
\text { and herbaceous habitats was detected; abundance was } \\
\text { significantly correlated with percent litter cover in corn } \\
\text { stubble; abundance was not correlated with percent litter } \\
\text { cover in soybean stubble, to waste corn abundance, to weed } \\
\text { seed density, or to distance to pasture or brushy habitats; } \\
\text { abundance increased as distance to woodlots and to alfalfa } \\
\text { haylands increased }\end{array}$ \\
\hline Harrison 1974 & Michigan & Tame hayland & $\begin{array}{l}\text { Occupied areas of low litter and low vegetation density; } \\
\text { territories were located in xeric, sparsely vegetated areas; } \\
\text { continued breeding activities following mowing in late } \\
\text { June, but breeding was terminated after the second mowing } \\
\text { in early August; used mowed field for foraging; areas used } \\
\text { by Vesper Sparrows were characterized by } 51.3 \% \text { litter } \\
\text { cover, } 51.2 \mathrm{~cm} \text { vegetation height, } 63 \% \text { light intensity, } 48 \\
\text { vegetation contacts/cm at } 5 \mathrm{~cm} \text { high, and } 122 \text { vegetation } \\
\text { contacts } / \mathrm{cm}^{2}\end{array}$ \\
\hline Hartley $1994 a, b$ & Saskatchewan & Cropland, DNC (idle & Were present in DNC, native grassland, and wheat fields \\
\hline
\end{tabular}




\begin{tabular}{|c|c|c|c|}
\hline & & $\begin{array}{l}\text { seeded-native, idle } \\
\text { seeded-native/tame, } \\
\text { idle tame, idle tame } \\
\text { hayland), idle mixed- } \\
\text { grass }\end{array}$ & \\
\hline Herkert 1994 & Illinois & $\begin{array}{l}\text { Burned seeded-native, } \\
\text { burned tallgrass }\end{array}$ & Were most abundant first growing season postburn \\
\hline Johnsgard 1980 & Nebraska & $\begin{array}{l}\text { Cropland, idle, idle } \\
\text { mixed-grass, idle } \\
\text { shortgrass, idle } \\
\text { tallgrass, tame } \\
\text { hayland, wet meadow }\end{array}$ & $\begin{array}{l}\text { Used idle fields, prairie edges, and areas where grassland } \\
\text { was mixed with scattered shrubs or low trees }\end{array}$ \\
\hline $\begin{array}{l}\text { Johnson and Schwartz } \\
\text { 1993, Johnson and Igl } \\
1995\end{array}$ & $\begin{array}{l}\text { Minnesota, } \\
\text { Montana, } \\
\text { North Dakota, } \\
\text { South Dakota }\end{array}$ & $\begin{array}{l}\text { Cropland, CRP (idle } \\
\text { seeded-native, idle } \\
\text { tame) }\end{array}$ & Were more common in cropland than CRP \\
\hline Kantrud 1981 & North Dakota & $\begin{array}{l}\text { Mixed-grass hayland, } \\
\text { mixed-grass pasture }\end{array}$ & $\begin{array}{l}\text { Density was about equal among heavily, moderately, and } \\
\text { lightly grazed areas; avoided hayland that was mowed the } \\
\text { previous year }\end{array}$ \\
\hline $\begin{array}{l}\text { Kantrud and Kologiski } \\
1982\end{array}$ & $\begin{array}{l}\text { Colorado, } \\
\text { Montana, } \\
\text { Nebraska } \\
\text { North Dakota, } \\
\text { South Dakota, } \\
\text { Wyoming }\end{array}$ & $\begin{array}{l}\text { Mixed-grass pasture, } \\
\text { shortgrass pasture, } \\
\text { shrubsteppe }\end{array}$ & $\begin{array}{l}\text { Were common on typic and aridic boroll soils and on } \\
\text { borollic and ustic aridisol soils; were not common on typic } \\
\text { and aridic ustoll soils; densities were highest on moderately } \\
\text { grazed ( } 20 \mathrm{~cm} \text { average vegetation height and } 17 \% \text { bare soil) } \\
\text { borollic aridisol soils and lightly grazed ( } 23 \mathrm{~cm} \text { average } \\
\text { vegetation height and } 9 \% \text { bare soil) ustic aridisol soils; } \\
\text { plots that had the highest number of Vesper Sparrows also } \\
\text { contained above-average abundance of wheatgrass, } \\
\text { Junegrass, fringed sagewort (Artemisia frigida), and big } \\
\text { sagebrush }\end{array}$ \\
\hline
\end{tabular}




\begin{tabular}{|c|c|c|c|}
\hline $\begin{array}{l}\text { Kantrud and Kologiski } \\
1983\end{array}$ & $\begin{array}{l}\text { Colorado, } \\
\text { Montana, } \\
\text { Nebraska } \\
\text { North Dakota, } \\
\text { South Dakota, } \\
\text { Wyoming }\end{array}$ & $\begin{array}{l}\text { Mixed-grass pasture, } \\
\text { shortgrass pasture, } \\
\text { shrubsteppe }\end{array}$ & $\begin{array}{l}\text { Densities were high in shrubsteppe/grassland and } \\
\text { shrubsteppe habitats }\end{array}$ \\
\hline $\begin{array}{l}\text { Lokemoen and Beiser } \\
1997\end{array}$ & North Dakota & Cropland, idle & $\begin{array}{l}\text { Second most frequently observed species in conventional- } \\
\text { tillage (spring and fall tillage and pesticide use), minimum- } \\
\text { tillage, and organic fields in fallow, sunflower, and wheat } \\
\text { fields; nested mainly in conventional-tillage fields }\end{array}$ \\
\hline Maher 1974 & Saskatchewan & $\begin{array}{l}\text { Cropland, } \\
\text { idle mixed-grass, } \\
\text { mixed-grass pasture, } \\
\text { tame hayland, } \\
\text { woodland }\end{array}$ & $\begin{array}{l}\text { Common summer resident in brushy habitats; uncommon } \\
\text { on grasslands }\end{array}$ \\
\hline McGee 1976 & Wyoming & $\begin{array}{l}\text { Burned shrubsteppe, } \\
\text { shrubsteppe }\end{array}$ & $\begin{array}{l}\text { Present on control and on spring-burned area } 1-3 \text { yr } \\
\text { postburn; were present on fall-burned area before the area } \\
\text { was burned but not } 2 \text { yr postburn }\end{array}$ \\
\hline $\begin{array}{l}\text { McMaster and Davis } \\
1998\end{array}$ & $\begin{array}{l}\text { Alberta, } \\
\text { Manitoba, } \\
\text { Saskatchewan }\end{array}$ & $\begin{array}{l}\text { Cropland, Permanent } \\
\text { Cover Program (PCP; } \\
\text { idle tame, tame } \\
\text { hayland, tame pasture) }\end{array}$ & $\begin{array}{l}\text { Occurred significantly more frequently in PCP than in } \\
\text { cropland; frequency of occurrence was higher in PCP sites } \\
\text { surrounded by grasslands than in PCP sites surrounded by } \\
\text { cropland, wetland, woodland, or human settlement; no } \\
\text { significant difference in frequency of occurrence between } \\
\text { PCP sites that were hayed and those that were grazed }\end{array}$ \\
\hline McMaster et al. 1999 & Saskatchewan & $\begin{array}{l}\text { Hayland, PCP (tame } \\
\text { hayland) }\end{array}$ & $\begin{array}{l}\text { Amount of cropland or wetland within } 1.6 \mathrm{~km} \text { of study } \\
\text { areas, area of hayland, area of hayland plus contiguous } \\
\text { perennial grassland (referred to as the grass patch), grass } \\
\text { patch edge density, and grass patch shape and complexity } \\
\text { did not affect number of indicated pairs or nest success }\end{array}$ \\
\hline
\end{tabular}




\begin{tabular}{|c|c|c|c|}
\hline Owens and Myres 1973 & Alberta & $\begin{array}{l}\text { Cropland, idle mixed- } \\
\text { grass, mixed-grass } \\
\text { hayland, mixed-grass } \\
\text { pasture }\end{array}$ & $\begin{array}{l}\text { Were more common on roadside censuses along cultivated } \\
\text { land ( } 66 \% \text { cultivated, } 30 \% \text { rough fescue (Festuca } \\
\text { scabrella) pasture, and } 4 \% \text { tame grassland) than censuses } \\
\text { along native grassland ( } 99 \% \text { native rough fescue, } 1 \% \\
\text { cultivated); significantly more common in censuses near } \\
\text { cultivated land than in censuses near pastures or near } \\
\text { cultivated and grazed areas, and at censuses near pasture } \\
\text { than censuses near undisturbed (unmowed } \geq 3 \text { yr) areas }\end{array}$ \\
\hline $\begin{array}{l}\text { Patterson 1994, Patterson } \\
\text { and Best } 1996\end{array}$ & Iowa & $\begin{array}{l}\text { Cropland, CRP (idle } \\
\text { tame, tame hayland) }\end{array}$ & $\begin{array}{l}\text { Nested in both rowcrop and CRP fields but were more } \\
\text { common in rowcrops }\end{array}$ \\
\hline $\begin{array}{l}\text { Perritt 1987, Perritt and } \\
\text { Best } 1989\end{array}$ & Iowa & Cropland & $\begin{array}{l}\text { Based on } 74 \text { territories found in } 2 \text { yr, territories were } \\
\text { characterized by mean values of } 3.31 \text { ha territory size, } 196 \\
\text { m fencerow length, } 216 \mathrm{~m} \text { territory width perpendicular to a } \\
\text { fencerow, } 1412 \mathrm{~m}^{2} \text { nonproductive area, } 1.2 \text { nonproductive } \\
\text { areas, } 3.3 \text { cultivations, and } 55 \% \text { of the territory planted in } \\
\text { soybeans; territory size was negatively correlated to } \\
\text { percentage of territory planted to soybeans and positively } \\
\text { correlated to territory width perpendicular to the fencerow } \\
\text { and to length of the fencerow; male Vesper Sparrows } \\
\text { appeared to adjust the length of fencerow relative to } \\
\text { fencerow width and height such that fencerow volume was } \\
\text { relatively constant ( } 405 \text { to } 588 \mathrm{~m}^{3} \text { ) }\end{array}$ \\
\hline Petersen and Best 1987 & Idaho & $\begin{array}{l}\text { Burned shrubsteppe, } \\
\text { idle shrubsteppe }\end{array}$ & Were present 3-4 yr postburn but were absent preburn \\
\hline Prescott 1997 & Alberta & $\begin{array}{l}\text { Cropland, hayland, } \\
\text { mixed-grass pasture, } \\
\text { shrubland, tame }\end{array}$ & $\begin{array}{l}\text { Were present in sandhill grasslands, tame pastures, } \\
\text { hayfields, coulees, badlands, mixed-grass, planted } \\
\text { croplands, upland shrub, fallow croplands, riparian shrub, }\end{array}$ \\
\hline
\end{tabular}




\begin{tabular}{|c|c|c|c|}
\hline & & pasture, woodland & and shelterbelts \\
\hline $\begin{array}{l}\text { Prescott and Murphy } \\
1996\end{array}$ & Alberta & $\begin{array}{l}\text { Mixed-grass pasture, } \\
\text { tame pasture }\end{array}$ & $\begin{array}{l}\text { Were common in both tame and native pastures; in native } \\
\text { pasture, appeared in areas with moderate cover diversity } \\
\text { and short grass; in tame pasture, appeared in areas with } \\
\text { moderate amounts of herbaceous biomass, moderate to low } \\
\text { variation in herbaceous height, and moderate to high } \\
\text { proportion of forbs relative to grasses; in tame pastures, } \\
\text { highest abundance was at moderate variation in herbaceous } \\
\text { height }\end{array}$ \\
\hline $\begin{array}{l}\text { Prescott and Murphy } \\
1999\end{array}$ & Alberta & $\begin{array}{l}\text { Cropland, DNC (idle } \\
\text { seeded-native/tame) }\end{array}$ & $\begin{array}{l}\text { Were present in low abundance on 1-, 3-, and 4-yr-old DNC } \\
\text { fields and were absent in cropland }\end{array}$ \\
\hline Prescott et al. 1995 & Alberta & $\begin{array}{l}\text { Cropland, DNC (idle } \\
\text { seeded-native, idle } \\
\text { tame), idle mixed- } \\
\text { grass, idle parkland, } \\
\text { idle tame, mixed-grass } \\
\text { pasture, parkland } \\
\text { pasture, tame hayland, } \\
\text { tame pasture, wetland, } \\
\text { woodland }\end{array}$ & $\begin{array}{l}\text { Were most abundant in deferred grazed tame and native } \\
\text { grasslands, followed by idle native grassland, continuously } \\
\text { grazed native grassland, delayed haylands, shrub, idle tame } \\
\text { grassland, tame pasture, continuously grazed native } \\
\text { parkland, tame DNC, and idle native parkland; were absent } \\
\text { from idle deciduous upland, conventional hayfields, } \\
\text { cropland, native DNC, shelterbelts, and saline or fresh } \\
\text { wetlands }\end{array}$ \\
\hline Prescott and Wagner 1996 & Alberta & $\begin{array}{l}\text { Mixed-grass pasture, } \\
\text { tame pasture }\end{array}$ & $\begin{array}{l}\text { Found in low occurrence in tame pasture, early-season } \\
\text { grazed native pasture, and deferred-grazed native pasture, } \\
\text { absent from continuously grazed native pasture }\end{array}$ \\
\hline Pylypec 1991 & Saskatchewan & $\begin{array}{l}\text { Burned mixed-grass, } \\
\text { idle mixed-grass }\end{array}$ & Preferred area 1 yr postburn over unburned area \\
\hline \multirow[t]{2}{*}{ Rand 1948} & Alberta & $\begin{array}{l}\text { Cropland, idle } \\
\text { shortgrass, shortgrass } \\
\text { pasture }\end{array}$ & $\begin{array}{l}\text { Were common in open, arid, closely-grazed shortgrass } \\
\text { prairie }\end{array}$ \\
\hline & & & Were observed in short, dense vegetation with a high \\
\hline
\end{tabular}




\begin{tabular}{|c|c|c|c|}
\hline Reed 1986 & Montana & Not given & $\begin{array}{l}\text { percentage of ground cover; mean values for } 52 \text { sampling } \\
\text { points within territories were } 20 \mathrm{~cm} \text { vegetation height, } \\
351 \% \text { ground cover (cumulative percent cover where } \\
\text { maximum was } 400 \% \text { ), } 145 \% \text { grass cover, } 206 \% \text { forb cover, } \\
4 \text { contacts (vertical vegetation density), and } 90 \mathrm{~cm} \text { height of } \\
\text { nearest perch }\end{array}$ \\
\hline Roberts 1932 & Minnesota & $\begin{array}{l}\text { Cropland, idle } \\
\text { tallgrass, woodland }\end{array}$ & $\begin{array}{l}\text { Were common in open, dry uplands, either native or } \\
\text { cultivated, as well as in cleared forest areas that had been } \\
\text { burned, cut, or that were created by windfall }\end{array}$ \\
\hline $\begin{array}{l}\text { Rodenhouse 1981, } \\
\text { Rodenhouse and Best } \\
1983\end{array}$ & Iowa & Cropland & $\begin{array}{l}\text { Territories were located linearly along fencerows and } \\
\text { included areas of cropland adjacent to the fencerows but } \\
\text { rarely extended }>80 \text { m into fields; } 42 \text { territories were } \\
\text { characterized by an average of } 3.7 \text { shrub groups per } \\
\text { territory, } 0.7 \text { washes, } 0.5 \text { weedy areas, } 0.4 \text { grassy } \\
\text { waterways, } 164 \mathrm{~m} \text { fencerow length, } 377 \mathrm{~m}^{2} \text { fencerow } \\
\text { coverage, } 400 \mathrm{~m}^{2} \text { coverage of washes, } 1700 \mathrm{~m}^{2} \text { coverage of } \\
\text { nonproductive areas, } 700 \mathrm{~kg} / \text { ha soybean residue before } \\
\text { planting, } 500 \mathrm{~kg} / \mathrm{ha} \text { soybean residue after planting, } 2400 \\
\mathrm{~kg} / \text { ha corn residue before planting, } 900 \mathrm{~kg} / \mathrm{ha} \text { corn residue } \\
\text { after planting, and } 2.34 \text { ha territory size; use of perch sites } \\
\text { and nest placement changed seasonally }\end{array}$ \\
\hline $\begin{array}{l}\text { Rotenberry and Wiens } \\
1980\end{array}$ & $\begin{array}{l}\text { Colorado, } \\
\text { Kansas, } \\
\text { Montana, } \\
\text { Nebraska, } \\
\text { Oklahoma, } \\
\text { Oregon, } \\
\text { South Dakota, } \\
\text { Texas, } \\
\text { Washington, } \\
\text { Wisconsin, }\end{array}$ & $\begin{array}{l}\text { Idle mixed-grass, idle } \\
\text { shortgrass, idle } \\
\text { shrubsteppe, idle } \\
\text { tallgrass, montane } \\
\text { meadow }\end{array}$ & $\begin{array}{l}\text { Abundance was positively correlated with forb cover and } \\
\text { amount of variation in height of nearest forb or shrub }\end{array}$ \\
\hline
\end{tabular}




\begin{tabular}{|c|c|c|c|}
\hline & Wyoming & & \\
\hline Salt and Salt 1976 & Alberta & $\begin{array}{l}\text { Cropland, idle, idle } \\
\text { grassland, parkland, } \\
\text { pasture }\end{array}$ & $\begin{array}{l}\text { Nested on ground in grass nests lined with hair and fine } \\
\text { grass; Vesper Sparrow originally nested on shortgrass } \\
\text { prairie but have adapted to cultivation and settlement; } \\
\text { stubble was avoided for everything except feeding; used } \\
\text { grass patches by roads, under fence lines, or on coulee } \\
\text { slopes; in parklands or woodlands, Vesper Sparrows } \\
\text { occurred in extensive meadows or pastures where grass was } \\
\text { not too tall or thick and used aspen (Populus) trees, fence } \\
\text { posts, and fence lines for perches }\end{array}$ \\
\hline Sample 1989 & Wisconsin & $\begin{array}{l}\text { Burned tallgrass, } \\
\text { cropland, DNC (idle } \\
\text { seeded-native, idle } \\
\text { tame), idle, idle } \\
\text { seeded-native, idle } \\
\text { tallgrass, idle } \\
\text { tallgrass/tame, idle } \\
\text { tame, tame hayland, } \\
\text { tame pasture, tame } \\
\text { savanna pasture, wet } \\
\text { meadow, wet-meadow } \\
\text { pasture }\end{array}$ & $\begin{array}{l}\text { Density was significantly greater in barrens than in any } \\
\text { other habitat; preferred dry habitats with short, sparse, and } \\
\text { patchy vegetation; used areas with an average of } 3 \% \text { woody } \\
\text { cover, } 68 \% \text { herbaceous cover, } 16 \% \text { litter cover, } 13 \% \text { bare } \\
\text { ground, } 62 \mathrm{~cm} \text { maximum vegetation height and } 21 \mathrm{~cm} \\
\text { vegetation height/density; density was positively correlated } \\
\text { with percent woody cover, percent bare ground, total } \\
\text { number of dead stems, low density of prostrate residual } \\
\text { vegetation, and proportion of burned plots; density was } \\
\text { negatively correlated with height/density and percent } \\
\text { standing residual vegetation }\end{array}$ \\
\hline Saunders 1914 & Montana & $\begin{array}{l}\text { Idle shortgrass, } \\
\text { montane meadow, } \\
\text { woodland }\end{array}$ & Were abundant on prairies and mountain meadows \\
\hline Schaid et al. 1983 & $\begin{array}{l}\text { South Dakota, } \\
\text { Wyoming }\end{array}$ & Shrubsteppe & $\begin{array}{l}\text { Density was significantly greater in unmined } \\
\text { grass/sagebrush areas than in unreclaimed or reclaimed } \\
\text { mining sites, and density was similar between the two } \\
\text { mined treatments; lack of sagebrush in the mined sites may } \\
\text { have accounted for lower density; nested on the ground } \\
\text { under big sagebrush in grass/sagebrush and unreclaimed }\end{array}$ \\
\hline
\end{tabular}




\begin{tabular}{|c|c|c|c|}
\hline & & & $\begin{array}{l}\text { site, but did not nest on the reclaimed site probably because } \\
\text { of lack of shrubs; used sagebrush for song perches; percent } \\
\text { frequency of occurrence of big sagebrush was a statistically } \\
\text { significant variable explaining variation in Vesper Sparrow } \\
\text { densities in the unreclaimed sites; percent frequency of } \\
\text { occurrence of green needlegrass was a statistically } \\
\text { significant variable explaining variation in Vesper Sparrow } \\
\text { densities in the reclaimed sites, probably because Vesper } \\
\text { Sparrows foraged on seeds of green needlegrass; surface } \\
\text { area of water, litter, percent frequency of occurrence of } \\
\text { Junegrass, and average height of vegetation were positively } \\
\text { associated with variation in Vesper Sparrow densities in } \\
\text { unmined areas, whereas percent frequency of occurrence of } \\
\text { forbs, shrubs and Japanese brome (Bromus japonicus) were } \\
\text { negatively associated with variation in Vesper Sparrow } \\
\text { densities in unmined areas }\end{array}$ \\
\hline Shutler et al. 2000 & Saskatchewan & $\begin{array}{l}\text { Cropland, DNC (idle } \\
\text { seeded-native, idle } \\
\text { seeded-tame), wetland }\end{array}$ & $\begin{array}{l}\text { Were more abundant in cropland on organic farmland than } \\
\text { on conventional or minimum-tillage farmland or in DNC; } \\
\text { presence was negatively related to number of wetlands } \\
\text { within } 2.8 \mathrm{~km}^{2} \text { of point counts; were detected in wetlands } \\
\text { or wetland margins within all farmland types and within } \\
\text { DNC; presence was positively related to percent woody } \\
\text { vegetation around wetland margin }\end{array}$ \\
\hline Skinner et al. 1984 & Missouri & $\begin{array}{l}\text { Burned tallgrass, idle } \\
\text { tallgrass, tallgrass } \\
\text { hayland, tallgrass } \\
\text { pasture, tame pasture }\end{array}$ & $\begin{array}{l}\text { Used short cover ( } 35 \% \text { cover at } 1 \mathrm{~cm} \text { and } 10 \% \text { cover at } 25 \\
\mathrm{~cm} \text { ); were most common in heavily grazed oldfields }\end{array}$ \\
\hline Stewart 1975 & North Dakota & $\begin{array}{l}\text { Cropland, grassland } \\
\text { edge, woodland edge }\end{array}$ & $\begin{array}{l}\text { Were common along field and prairie edges and along } \\
\text { shelterbelts and weedy fencerows in cropland areas; } \\
\text { occurred in thickets, scattered small trees and shrubs, } \\
\text { patches of coarse forbs and/or weeds contiguous with tracts }\end{array}$ \\
\hline
\end{tabular}




\begin{tabular}{|c|c|c|c|}
\hline & & & $\begin{array}{l}\text { of cropland, hayland, or open prairie; nested on ground in } \\
\text { sparse to fairly dense herbaceous vegetation }\end{array}$ \\
\hline Sutter and Brigham 1998 & Saskatchewan & $\begin{array}{l}\text { Mixed-grass pasture, } \\
\text { tame pasture }\end{array}$ & $\begin{array}{l}\text { Abundance did not significantly differ between native } \\
\text { mixed-grass and crested wheatgrass (Agropyron cristatum) }\end{array}$ \\
\hline Sutter et al. 2000 & Saskatchewan & Mixed-grass pasture & $\begin{array}{l}\text { Abundance in mixed-grass prairie was twice as high along } \\
\text { roadsides than along trailsides }\end{array}$ \\
\hline Volkert 1992 & Wisconsin & $\begin{array}{l}\text { Burned tallgrass } \\
\text { (restored), idle } \\
\text { tallgrass (restored) }\end{array}$ & $\begin{array}{l}\text { Occurred after a burn in an area that had been reseeded } 3 \text { yr } \\
\text { previously; reached highest abundance the next year but } \\
\text { declined to zero by the } 5 \text { th yr postburn }\end{array}$ \\
\hline Whitmore 1979 & West Virginia & Idle tame & $\begin{array}{l}\text { Territories upon spring arrival were characterized by } 17 \% \\
\text { basal area cover of grass, } 6 \% \text { forb cover, } 53 \% \text { litter cover, } \\
44 \% \text { bare ground, } 1 \mathrm{~cm} \text { litter depth, } 8 \mathrm{~cm} \text { forb height, and } \\
26 \mathrm{~cm} \text { effective vegetation height; territories during peak } \\
\text { breeding season were characterized by } 6 \% \text { basal area cover } \\
\text { of grass, } 14 \% \text { forb cover, } 56 \% \text { litter cover, } 44 \% \text { bare } \\
\text { ground, } 1 \mathrm{~cm} \text { litter depth, and } 14 \mathrm{~cm} \text { forb height }\end{array}$ \\
\hline Wiens 1969 & Wisconsin & $\begin{array}{l}\text { Idle pasture, tame } \\
\text { pasture }\end{array}$ & $\begin{array}{l}\text { Observed in dry, upland pasture with sparse grass and forb } \\
\text { cover; average territory size of five territories was } 0.88 \text { ha; } \\
\text { all territories were along fence lines and were characterized } \\
\text { by } 96 \% \text { grass cover, } 30 \% \text { forb cover, and } 3 \% \text { bare ground; } \\
\text { for } 5 \text { territories, mean distance from territory boundary to } \\
\text { woods was } 246 \mathrm{~m} \text {, to fence line was } 0 \mathrm{~m} \text {, and to cultivated } \\
\text { field was } 69 \mathrm{~m} \text {; all territories contained fence posts and } \\
\text { fence lines }\end{array}$ \\
\hline $\begin{array}{l}\text { Wiens and Rotenberry } \\
1981\end{array}$ & $\begin{array}{l}\text { Nevada, } \\
\text { Oregon }\end{array}$ & Idle shrubsteppe & $\begin{array}{l}\text { Density was positively and significantly correlated with } \\
\text { diversity of coverage in plant structural types; abundance } \\
\text { was positively and significantly correlated with cover of } \\
\text { green rabbitbrush (Chrysothamnus viscidiflorus) and } \\
\text { antelope bitterbrush (Purshia tridentata) }\end{array}$ \\
\hline
\end{tabular}




\begin{tabular}{|l|l|l|l|}
\hline Wilson and Belcher 1989 & Manitoba & $\begin{array}{l}\text { Idle mixed-grass, idle } \\
\text { tame }\end{array}$ & $\begin{array}{l}\text { Abundance was positively correlated with tame vegetation } \\
\text { and negatively correlated with native vegetation }\end{array}$ \\
\hline Wray and Whitmore 1979 & West Virginia & Idle tame & $\begin{array}{l}\text { Successful nest sites were characterized by higher vertical } \\
\text { vegetation density, more litter cover, and less bare ground } \\
\text { than unsuccessful nest sites }\end{array}$ \\
\hline Yahner 1982 & Minnesota & Woodland & $\begin{array}{l}\text { Were most common in the midstory and ground strata of } \\
\text { shelterbelts; no tree or shrub preference was observed }\end{array}$ \\
\hline
\end{tabular}

* In an effort to standardize terminology among studies, various descriptors were used to denote the management or type of habitat. "Idle" used as a modifier (e.g., idle tallgrass) denotes undisturbed or unmanaged (e.g., not burned, mowed, or grazed) areas. "Idle" by itself denotes unmanaged areas in which the plant species were not mentioned. Examples of "idle" habitats include weedy or fallow areas (e.g., oldfields), fencerows, grassed waterways, terraces, ditches, and road rights-of-way. "Tame" denotes introduced plant species (e.g., smooth brome [Bromus inermis]) that are not native to North American prairies. "Hayland" refers to any habitat that was mowed, regardless of whether the resulting cut vegetation was removed. "Burned" includes habitats that were burned intentionally or accidentally or those burned by natural forces (e.g., lightning). In situations where there are two or more descriptors (e.g., idle tame hayland), the first descriptor modifies the following descriptors. For example, idle tame hayland is habitat that is usually mowed annually but happened to be undisturbed during the year of the study. 


\section{LITERATURE CITED}

Anstey, D. A., S. K. Davis, D. C. Duncan, and M. Skeel. 1995. Distribution and habitat requirements of eight grassland songbird species in southern Saskatchewan. Saskatchewan Wetland Conservation Corporation, Regina, Saskatchewan. 11 pages.

Arnold, T. W., and K. F. Higgins. 1986. Effects of shrub coverages on birds of North Dakota mixed-grass prairies. Canadian Field-Naturalist 100:10-14.

Basore, N. S., L. B. Best, and J. B. Wooley. 1986. Bird nesting in Iowa no-tillage and tilled cropland. Journal of Wildlife Management 50:19-28.

Batts, H. L., Jr. 1958. The distribution and population of nesting birds on a farm in southern Michigan. Jack-Pine Warbler 36:131-149.

Berger, A. J. 1968. Eastern Vesper Sparrow. Pages 868-882 in O. L. Austin, Jr., editor. Life histories of North American cardinals, grosbeaks, buntings, towhees, finches, sparrows, and allies. Dover Publications, Inc., New York, New York.

Best, L. B. 1972. First-year effects of sagebrush control on two sparrows. Journal of Wildlife Management 36:534-544.

Best, L. B. 1983. Bird use of fence rows: implications of contemporary fencerow management practice. Wildlife Society Bulletin 11:343-347.

Best, L. B., H. Campa, III, K. E. Kemp, R. J. Robel, M. R. Ryan, J. A. Savidge, H. P. Weeks, Jr., and S. R. Winterstein. 1997. Bird abundance and nesting in CRP fields and cropland in the Midwest: a regional approach. Wildlife Society Bulletin 25:864-877.

Best, L. B., and B. J. Hill. 1983. Fence rows are for the birds. Iowa Bird Life 53:16-21.

Best, L. B., and N. L. Rodenhouse. 1984. Territory preference of Vesper Sparrows in cropland. Wilson Bulletin 96:72-82.

Best, L. B., R. C. Whitmore, and G. M. Booth. 1990. Use of cornfields by birds during the breeding season: the importance of edge habitat. American Midland Naturalist 123:8499.

Bock, C. E., J. H. Bock, and B. C. Bennett. 1999. Songbird abundance in grasslands at a suburban interface on the Colorado High Plains. Pages 131-136 in P. D. Vickery and J. R. Herkert, editors. Ecology and conservation of grassland birds of the Western Hemisphere. Studies in Avian Biology 19.

Bryan, G. G., and L. B. Best. 1991. Bird abundance and species richness in grassed waterways in Iowa rowcrop fields. American Midland Naturalist 126:90-102.

Bryan, G. G., and L. B. Best. 1994. Avian nest density and success in grassed waterways in Iowa rowcrop fields. Wildlife Society Bulletin 22:583-592.

Cameron, E. S. 1908. The birds of Custer and Dawson counties, Montana. Auk 25:39-56. 
Camp, M., and L. B. Best. 1993. Bird abundance and species richness in roadsides adjacent to Iowa rowcrop fields. Wildlife Society Bulletin 21:315-325.

Camp, M., and L. B. Best. 1994. Nest density and nesting success of birds in roadsides adjacent to rowcrop fields. American Midland Naturalist 131:347-358.

Castrale, J. S. 1982. Effects of two sagebrush control methods for nongame birds. Journal of Wildlife Management 46:945-952.

Castrale, J. S. 1983. Selection of song perches by sagebrush-grassland birds. Wilson Bulletin 95:647-655.

Clark, T. W., T. W. Campbell III, D. G. Socha, and D. E. Cassey. 1982. Prairie dog colony attributes and associated vertebrate species. Great Basin Naturalist 42:572-582.

Dale, B. 1993. 1992 Saskatchewan non-game bird evaluation of North American Waterfowl Management Plan: DNC and short grass cover - 1992. Unpublished report. Canadian Wildlife Service, Edmonton, Alberta; Saskatchewan Wetland Conservation Corporation, Regina, Saskatchewan. 23 pages.

Davis, S. K., and D. C. Duncan. 1999. Grassland songbird occurrence in native and crested wheatgrass pastures of southern Saskatchewan. Pages 211-218 in J. Herkert and P. Vickery, editors. Ecology and conservation of grassland birds of the Western Hemisphere. Studies in Avian Biology 19.

Davis, S. K., D. C. Duncan, D. A. Anstey, and M. Skeel. 1997. Habitat selection of grassland songbirds in southern Saskatchewan. Unpublished report to the Saskatchewan Wetland Conservation Corporation, Regina, Saskatchewan. 31 pages.

Dhol, S., J. Horton, and R. E. Jones. 1994. 1994 non-waterfowl evaluation of Manitoba’s North American Waterfowl Management Plan. Unpublished report. Wildlife Branch, Manitoba Department of Natural Resources, Winnipeg, Manitoba. 12 pages.

Emmerich, J. M. 1978. Bird utilization of woodland habitat in the eastern quarter of South Dakota. M.S. thesis. South Dakota State University, Brookings, South Dakota. 130 pages.

Faanes, C. A. 1981. Birds of the St. Croix River Valley: Minnesota and Wisconsin. U.S. Fish and Wildlife Service, Washington, D.C. North American Fauna 73. 196 pages.

Faanes, C. A. 1983. Aspects of the nesting ecology of Least Terns and Piping Plovers in central Nebraska. Prairie Naturalist 15:145-154.

Faanes, C. A., and G. R. Lingle. 1995. Breeding birds of the Platte River Valley of Nebraska. Jamestown, ND: Northern Prairie Wildlife Research Center home page. http://www.npwrc.usgs.gov/resource/distr/birds/platte/platte.htm (Version 16JUL97).

Fautin, R. W. 1975. The terrestrial vertebrate fauna of the Atlantic Richfield Company's Black Thunder Coal lease property in Campbell County, Wyoming. Pages 635-650 in Fort Union Coal Field Symposium. 
Feist, F. G. 1968. Breeding bird populations in relation to proposed sagebrush control in central Montana. M.S. thesis. Montana State University, Bozeman, Montana. 41 pages.

Finzel, J. E. 1964. Avian populations of four herbaceous communities in southeastern Wyoming. Condor 66:496-510.

Frawley, B. J. 1989. The dynamics of nongame bird breeding ecology in Iowa alfalfa fields. M.S. thesis. Iowa State University, Ames, Iowa. 94 pages.

Frawley, B. J., and L. B. Best. 1991. Effects of mowing on breeding bird abundance and species composition in alfalfa fields. Wildlife Society Bulletin 19:135-142.

Friedmann, H. 1963. Host relations of the parasitic cowbirds. U.S. National Museum Bulletin 233:1-276.

George, J. L. 1952. The birds on a southern Michigan farm. Ph.D. dissertation. University of Michigan, Ann Arbor, Michigan. 413 pages.

George, T. L., L. C. McEwen, and A. Fowler. 1992. Effects of a carbaryl bait treatment on nontarget wildlife. Environmental Entomology 21:1239-1247.

George, T. L., L. C. McEwen, and B. E. Peterson. 1995. Effects of grasshopper control programs on rangeland breeding bird populations. Journal of Range Management 48:336-342.

Graber, R. R., and J. W. Graber. 1963. A comparative study of bird populations in Illinois, 1906-1909 and 1956-1958. Illinois Natural History Survey Bulletin 28:383-528.

Gremaud, G. K. 1983. Factors influencing nongame bird use of rowcrop fields. M.S. thesis. Iowa State University, Ames, Iowa. 56 pages.

Gruver, B. J., and F. S. Guthery. 1986. Effects of brush control and game-bird management on nongame birds. Journal of Range Management 39:251-253.

Harrison, K. G. 1974. Aspects of habitat selection in grassland birds. M.S. thesis. Western Michigan University, Kalamazoo, Michigan. 82 pages.

Harrison, K. G. 1977. Perch height selection of grassland birds. Wilson Bulletin 89:486-487.

Hartley, M. J. 1994a. Passerine abundance and productivity indices in grasslands managed for waterfowl nesting cover. Transactions of the North American Wildlife and Natural Resources Conference 59:322-327.

Hartley, M. J. 1994b. Passerine abundance and productivity indices in grasslands managed for waterfowl nesting cover in Saskatchewan, Canada. M.S. thesis. Louisiana State University, Baton Rouge, Louisiana. 42 pages.

Herkert, J. R. 1991a. An ecological study of the breeding birds of grassland habitats within Illinois. Ph.D. dissertation. University of Illinois, Urbana, Illinois. 112 pages. 
Herkert, J. R. 1991b. Prairie birds of Illinois: population response to two centuries of habitat change. Illinois Natural History Survey Bulletin 34:393-399.

Herkert, J. R. 1994. Breeding bird communities of midwestern prairie fragments: the effects of prescribed burning and habitat-area. Natural Areas Journal 14:128-135.

Janssen, R. B. 1987. Birds in Minnesota. University of Minnesota Press, Minneapolis, Minnesota. 352 pages.

Johnsgard, P. A. 1980. A preliminary list of the birds of Nebraska and adjacent Plains states. University of Nebraska, Lincoln, Nebraska. 156 pages.

Johnson, D. H., and L. D. Igl. 1995. Contributions of the Conservation Reserve Program to populations of breeding birds in North Dakota. Wilson Bulletin 107:709-718.

Johnson, D. H., and M. D. Schwartz. 1993. The Conservation Reserve Program and grassland birds. Conservation Biology 7:934-937.

Kantrud, H. A. 1981. Grazing intensity effects on the breeding avifauna of North Dakota native grasslands. Canadian Field-Naturalist 95:404-417.

Kantrud, H. A. 1982. Maps of distribution and abundance of selected species of birds on uncultivated native upland grasslands and shrubsteppe in the northern Great Plains. U.S. Fish and Wildlife Service Biological Services Program FWS/OBS-82/31. 31 pages.

Kantrud, H. A., and R. L. Kologiski. 1982. Effects of soils and grazing on breeding birds of uncultivated upland grasslands of the northern Great Plains. U.S. Fish and Wildlife Service, Wildlife Research Report 15. 33 pages.

Kantrud, H. A., and R. L. Kologiski. 1983. Avian associations of the northern Great Plains grasslands. Journal of Biogeography 10:331-350.

Kent, T. H., and J. J. Dinsmore. 1996. Birds in Iowa. Published by the authors, Iowa City and Ames, Iowa. 391 pages.

Kerley, L. L., and S. H. Anderson. 1995. Songbird responses to sagebrush removal in a high elevation sagebrush steppe ecosystem. Prairie Naturalist 27:129-146.

Klimkiewicz, M. K. and A. G. Futcher. 1987. Longevity records of North American birds: Coerebinae through Estrildidae. Journal of Field Ornithology 58:318-333.

Knapton, R. W. 1979. Birds of the Gainsborough-Lyleton region. Saskatchewan Natural History Society Special Publication 10. 72 pages.

Knapton, R. W., and P. Mineau. 1995. Effects of granular formulations of terbufos and fonofos applied to cornfields on mortality and reproductive success of songbirds. Ecotoxicology 4:138-153.

Lokemoen, J. T., and J. A. Beiser. 1997. Bird use and nesting in conventional, minimumtillage, and organic cropland. Journal of Wildlife Management 61:644-655. 
Maher, W. J. 1973. Matador Project: Birds I. Population dynamics. Canadian Committee for the International Biological Programme, Matador Project, Technical Report 34. University of Saskatchewan, Saskatoon, Saskatchewan. 56 pages.

Maher, W. J. 1974. Matador Project: Birds II. Avifauna of the Matador area. Canadian Committee for the International Biological Programme, Matador Project, Technical Report 58. University of Saskatchewan, Saskatoon, Saskatchewan. 31 pages.

McEwen, L. C., C. E. Knittle, and M. L. Richmond. 1972. Wildlife effects from grasshopper insecticides sprayed on short-grass range. Journal of Range Management 25:188-194.

McGee, J. M. 1976. Some effects of fire suppression and prescribed burning on birds and small mammals in sagebrush. Ph.D. dissertation. University of Wyoming, Laramie, Wyoming. 114 pages.

McMaster, D. G., and S. K. Davis. 1998. Non-game evaluation of the Permanent Cover Program. Unpublished report. Saskatchewan Wetland Conservation Corporation, Regina, Saskatchewan. $75+$ pages.

McMaster, D. G., J. H. Devries, and S. K. Davis. 1999. An integrated evaluation of cropland conversion in the Missouri Coteau of Saskatchewan: productivity of pintail and other grassland birds. Unpublished report. Saskatchewan Wetland Conservation Corporation, Regina, Saskatchewan; Institute for Wetland and Waterfowl Research, Oak Hammock Marsh, Manitoba; Ducks Unlimited Canada, Oak Hammock Marsh, Manitoba.

Miller, S. G., R. L. Knight, and C. K. Miller. 1998. Influence of recreational trails on breeding bird communities. Ecological Applications 8:162-169.

National Geographic Society. 1999. Field guide to the birds of North America, third edition. National Geographic Society, Washington, D.C. 480 pages.

Owens, R. A., and M. T. Myres. 1973. Effects of agriculture upon populations of native passerine birds of an Alberta fescue grassland. Canadian Journal of Zoology 51:697-713.

Patterson, M. P. 1994. Bird species abundance, composition, and vegetation characteristics, and bird productivity in Conservation Reserve Program land in central Iowa. M.S. thesis. Iowa State University, Ames, Iowa. 54 pages.

Patterson, M. P., and L. B. Best. 1996. Bird abundance and nesting success in Iowa CRP fields: the importance of vegetation structure and composition. American Midland Naturalist 135:153-167.

Perritt, J. E. 1987. Breeding ecology of Vesper Sparrows in Iowa crop fields: the effects of weather and habitat quality on territory selection. M.S. thesis. Iowa State University, Ames, Iowa. 45 pages.

Perritt, J. E., and L. B. Best. 1989. Effects of weather on the breeding ecology of Vesper Sparrows in Iowa crop fields. American Midland Naturalist 121:355-360. 
Petersen, K. L., and L. B. Best. 1987. Effects of prescribed burning on nongame birds in a sagebrush community. Wildlife Society Bulletin 15:317-329.

Prescott, D. R. C. 1997. Avian communities and NAWMP habitat priorities in the northern prairie biome of Alberta. Land Stewardship Centre of Canada. NAWMP-029. St. Albert, Alberta. 41 pages.

Prescott, D. R. C., and A. J. Murphy. 1996. Habitat associations of grassland birds on native and tame pastures of the aspen parkland in Alberta. NAWMP-021. Alberta NAWMP Centre, Edmonton, Alberta. 36 pages.

Prescott, D. R. C., and A. Murphy. 1999. Bird populations in seeded nesting cover on North American Waterfowl Management Plan properties in the aspen parkland of Alberta. Pages 203-210 in P. D. Vickery and J. R. Herkert, editors. Ecology and conservation of grassland birds of the Western Hemisphere. Studies in Avian Biology 19.

Prescott, D. R. C., A. J. Murphy, and E. Ewaschuk. 1995. An avian community approach to determining biodiversity values of NAWMP habitats in the aspen parkland of Alberta. NAWMP-012. Alberta NAWMP Centre, Edmonton, Alberta. 58 pages.

Prescott, D. R. C., and G. M. Wagner. 1996. Avian responses to implementation of a complementary/rotational grazing system by the North American Waterfowl Management Plan in southern Alberta: the Medicine Wheel Project. NAWMP-018. Alberta NAWMP Centre, Edmonton, Alberta. 24 pages.

Pylypec, B. 1991. Impacts of fire on bird populations in a fescue prairie. Canadian FieldNaturalist 105:346-349.

Rand, A. L. 1948. Birds of southern Alberta. National Museum of Canada, Ottawa, Canada. Bulletin no. 111. Biological Series, no. 37. 105 pages.

Reed, J. M. 1985. A comparison of the "flush" and spot-map methods for estimating the size of Vesper Sparrow territories. Journal of Field Ornithology 56:131-137.

Reed, J. M. 1986. Vegetation structure and Vesper Sparrow territory location. Wilson Bulletin 98:144-147.

Roberts, T. S. 1932. The birds of Minnesota, Volume 2. University of Minnesota Press, Minneapolis, Minnesota. 821 pages.

Rodenhouse, N. L. 1981. Breeding ecology of Vesper Sparrows in corn and soybean fields. M.S. thesis. Iowa State University, Ames, Iowa. 69 pages.

Rodenhouse, N. L., and L. B. Best. 1983. Breeding ecology of Vesper Sparrows in corn and soybean fields. American Midland Naturalist 110:265-275.

Rodenhouse, N. L., and L. B. Best. 1994. Foraging patterns of Vesper Sparrows (Pooecetes gramineus) breeding in cropland. American Midland Naturalist 131:196-206. 
Rotenberry, J. T., and J. A. Wiens. 1980. Habitat structure, patchiness, and avian communities in North American steppe vegetation: a multivariate analysis. Ecology 61:1228-1250.

Salt, W. R., and J. R. Salt. 1976. The birds of Alberta. Hurtig Publishers, Edmonton, Alberta. 498 pages.

Sample, D. W. 1989. Grassland birds in southern Wisconsin: habitat preference, population trends, and response to land use changes. M.S. thesis. University of Wisconsin, Madison, Wisconsin. 588 pages.

Saunders, A. A. 1914. The birds of Teton and northern Lewis and Clark counties, Montana. Condor 16:124-144.

Schaid, T. A., D. W. Uresk, W. L. Tucker, and R. L. Linder. 1983. Effects of surface mining on the Vesper Sparrow in the northern Great Plains. Journal of Range Management 36:500503.

Shaffer, J. A., C. M. Goldade, M. F. Dinkins, D. H. Johnson, L. D. Igl, and B. R. Euliss. 2003. Brown-headed Cowbirds in grasslands: their habitats, hosts, and response to management. Prairie Naturalist 35:146-186.

Shutler, D., A. Mullie, and R. G. Clark. 2000. Bird communities of prairie uplands and wetlands in relation to farming practices in Saskatchewan. Conservation Biology 14:1441-1451.

Skinner, R. M., T. S. Baskett, and M. D. Blendon. 1984. Bird habitat on Missouri prairies. Terrestrial Series 14. Missouri Department of Conservation, Jefferson City, Missouri. 37 pages.

Stallman, H. R. and L. B. Best. 1996. Bird use of an experimental strip intercropping system in northeast Iowa. Journal of Wildlife Management 60:354-362.

Stewart, R. E. 1975. Breeding birds of North Dakota. Tri-College Center for Environmental Studies, Fargo, North Dakota. 295 pages.

Sutter, G. C., and R. M. Brigham. 1998. Avifaunal and habitat changes resulting from conversion of native prairie to crested wheat grass: patterns at songbird community and species levels. Canadian Journal of Zoology 76:869-875.

Sutter, G. C., S. K. Davis, and D. C. Duncan. 2000. Grassland songbird abundance along roads and trails in southern Saskatchewan. Journal of Field Ornithology 71:110-116.

Temple, S. A., B. M. Fevold, L. K. Paine, D. J. Undersander, and D. W. Sample. 1999. Nesting birds and grazing cattle: accommodating both on midwestern pastures. Pages 196-202 in P. D. Vickery and J. R. Herkert, editors. Ecology and conservation of grassland birds of the Western Hemisphere. Studies in Avian Biology 19.

Vickery, P. D., M. L. Hunter, and S. M. Melvin. 1994. Effects of habitat area on the distribution of grassland birds in Maine. Conservation Biology 8:1087-1097. 
Volkert, W. K. 1992. Response of grassland birds to a large-scale prairie planting project. Passenger Pigeon 54:190-196.

Whitmore, R. C. 1979. Temporal variation in the selected habitats of a guild of grassland sparrows. Wilson Bulletin 91:592-598.

Wiens, J. A. 1969. An approach to the study of ecological relationships among grassland birds. Ornithological Monographs 8:1-93.

Wiens, J. A. 1971. Avian ecology and distribution in the comprehensive network, 1970. U.S. International Biological Program, Grassland Biome Technical Report 77. Colorado State University, Fort Collins, Colorado. 49 pages.

Wiens, J. A., and J. T. Rotenberry. 1981. Habitat associations and community structure in shrubsteppe environments. Ecological Monographs 51:21-41.

Wilson, S. D., and J. W. Belcher. 1989. Plant and bird communities of native prairie and introduced Eurasian vegetation in Manitoba, Canada. Conservation Biology 3:39-44.

Wray, T., III, and R. C. Whitmore. 1979. Effects of vegetation on nesting success of Vesper Sparrows. Auk 96:802-805.

Yahner, R. H. 1982. Avian use of vertical strata and plantings in farmstead shelterbelts. Journal of Wildlife Management 46:50-60. 
Appendix 1. Summary of Vesper Sparrow use of agricultural habitats in Iowa.

Territory characteristics for Vesper Sparrows inhabiting fence rows between cropland were examined in Iowa (Rodenhouse 1981, Best and Rodenhouse 1984, Perritt 1987, Perritt and Best 1989). Territories were located linearly along fence rows and included areas of the cropland adjacent to the fence rows; only one territory studied did not include a fence row (Rodenhouse 1981). Centers of fields were rarely used by Vesper Sparrows because territories did not extend $>80 \mathrm{~m}$ into fields. Paired males had more shrub groups (one or more shrubs or saplings forming a contiguous canopy) and more corn residue within their territories than did unpaired males. Males that arrived earlier in the breeding season had more shrubs in their territories and greater fence row coverage than those arriving later in the season. Only along herbaceous fence rows were portions of fence rows unoccupied by Vesper Sparrows, as opposed to fence rows with shrubs or saplings. Preferred territories had structurally diverse vegetation and high plant species richness. Of eight territories without a successful nest, six did not contain a wash (eroded areas in watercourses caused by cultivation); 11 territories with two successful nests contained an average of 1.1 washes (Best and Rodenhouse 1984). No territory preference, however, was exhibited for washes, perhaps because they did not exist at the time of territory selection for most Vesper Sparrows. During the last month of the breeding season, washes provided the only open habitat and were used heavily for nesting. Perritt (1987) found that there were fewer cultivations in territories with one successful nest and more cultivations in territories with no or two successful nests. Nest success may have been influenced by the interaction between number of cultivations and the type of crop planted within territories. Territories of pairs with no or one successful nest contained 50\% soybean and 50\% corn. Territories of pairs with two successful nests contained a higher proportion of soybeans, possibly because canopy closure occurred later in soybeans than in corn. The most successful breeding pairs experienced frequent disturbance from cultivation early in the breeding season but were able to overcome this because of the amount of soybeans in the territories. Territory size was smallest in territories with two successful nests than in territories with no or one successful nest. Territory size was negatively correlated with percentage of territory planted to soybeans and positively correlated with territory width perpendicular to the fence row.

Rodenhouse (1981) found that nest placement changed seasonally. Before spring tillage, Vesper Sparrows built nests near clumps of crop residue and within fields with high amounts of crop residue. On plowed fields with little residue, nesting sites were scarce until plants developed (Rodenhouse and Best 1983). After spring tillage operations, which destroyed some of the initial nests, subsequent nests were placed on the side of the fence row that was not the most recently tilled. After plants grew to $10 \mathrm{~cm}$ tall, nests were placed at the base of the growing plants. About $50 \%$ of the nests survived subsequent field operations. Later in the season, when the crop canopy had closed, nests were placed in washes. As the breeding season progressed and crop fields became more heavily vegetated, washes provided the only open areas for nesting. Early nests (initiated before 23 May) were placed closer to nonproductive areas (i.e., grassed waterways, washes, and weedy areas) than mid-season nests (initiated between 23 May and 19 June) that were built after initial nests had been destroyed (Rodenhouse and Best 1983). Insect populations may have been higher in nonproductive areas than in either fence rows or crops early in the breeding season, whereas the insect community was developing in cropland later in the breeding season. Also, the probability increased that a mid-season nest would be destroyed the closer the nest was to a nonproductive area (Rodenhouse 1981). This did not hold true for parasitized nests. Late nests (initiated after 19 June) were placed close to nonproductive areas, 
particularly fence rows and washes (Rodenhouse and Best 1983). Nests were usually in soybean fields because soybean plants concealed some nests and provided cover for adults approaching the nests, which were on sparsely vegetated areas.

Perritt and Best (1989) reported that reproductive success was greater in a wet year than in a dry year because of fewer cultivations and a longer breeding season due to late canopy closure and presence of more nonproductive areas. However, reproductive success may still not have been high enough to maintain a stable population. Under average climatic conditions, reproductive success was less than replacement rate (Rodenhouse and Best 1983 ). Low nesting success before mid-June was mostly attributed to nest destruction by agricultural field operations such as seedbed preparation, use of a rotary hoe for weed control after planting, or by cultivation. Through 15 June, 21\% of 29 nests were successful in corn and soybean fields; after that date, $44 \%$ of 16 nests were successful. Through 15 June, 17\% of 29 nests were parasitized; 0 of 16 nests were parasitized after 15 June. Overall, of 45 nests, 11\% were parasitized, 27\% were destroyed by farm implements, $29 \%$ were destroyed by depredation, and $4 \%$ were destroyed by weather (Rodenhouse and Best 1983).

Throughout the breeding season, Vesper Sparrows foraged in or near uncropped or weedy areas within their territories (Rodenhouse and Best 1994). In April and May, 68\% of 1055 foraging observations occurred in or within $1 \mathrm{~m}$ of an uncropped or weedy area. In June, foraging occurred in corn fields and in washes; crops concealed bird movement. In July and early August, half of 1996 observations occurred in or $<6 \mathrm{~m}$ from uncropped or weedy areas. Large areas within cropped areas, especially those areas $>50 \mathrm{~m}$ from an uncropped or weedy area, were avoided. There were no differences in foraging patterns between males and females. Throughout the breeding season, pairs preferred to forage in fields with the most crop residue. The authors theorized that Vesper Sparrows preferred areas with more remaining residue because these fields had higher song perches, more concealment cover, and contained more arthropods.

Nest densities were higher in strip cover than in fields of no-tillage corn or tilled corn (Basore et al. 1986). Strip cover consisted of waterways, terraces, fence rows, and roadside ditches. In no-tillage fields, Vesper Sparrows chose nest sites with less residue than that found in the field overall. Vesper Sparrows also nested along gravel roads situated between corn and/or soybean fields (Camp and Best 1994). Of seven nests, all were located on the foreslope (defined as the slope of the roadside between the road and the bottom of the ditch) where mowing and gravel kept the vegetation short. Nest densities were positively correlated with amount of bare ground and negatively correlated with vegetation density and vegetation height.

Stallman and Best (1996) investigated a system of strip intercropping, in which rowcrops, legumes, and small grains are planted in a series of adjacent, narrow strips. Vesper Sparrows preferred nesting in corn or soybean strips over oat strips. They placed nests under clumps of vegetation or crop residue. All nests in corn strips were placed under weeds, whereas there appeared no preference for nest location in soybean strips. Territories were in areas with elevated song perches and abundant food. About $40 \%$ of the nests were located $>80 \mathrm{~m}$ from fencerows.

Gremaud (1983) found that although abundance was similar in corn, soybean, and alfalfa stubble in one year, abundance was significantly higher in alfalfa stubble than in corn or soybean stubble the following year. Abundance was significantly correlated with percent litter cover in corn stubble. Abundance was not correlated with percent litter cover in soybean stubble, waste 
corn abundance, weed seed density, or distance to pasture or brushy habitats; abundance increased as distance to woodlots and to alfalfa haylands increased. 